\title{
Eekaulostomus cuevasae gen. and sp. nov., an ancient armored trumpetfish (Aulostomoidea) from Danian (Paleocene) marine deposits of Belisario Domínguez, Chiapas, southeastern Mexico
}

\author{
Kleyton Magno Cantalice and Jesús Alvarado-Ortega
}

\begin{abstract}
Eekaulostomus cuevasae gen. and sp. nov. is described and identified here as a new member of the superfamily Aulostomoidea. The single specimen known of this species is part of a newly fossil assemblage collected in the marine sediments belonging to the early Paleocene Tenejapa-Lacandón geological unit, exploited in the Belisario Domínguez quarry, near Palenque town, State of Chiapas, southeastern Mexico. $E$. cuevasae represents the oldest aulostomoid as far known and the first fossil species of this superfamily collected in America. E. cuevasae differs from other aulostomoids in the presence of two spines preceding the soft rays of both dorsal and anal fins; the star-like scales covering the entire body and part of the snout; as well as the relative large number of principal rays in the caudal fin. The recognition of $E$. cuevasae as the stem group of Aulostomoidea increases the temporal and geographic distribution of this superfamily up to Danian and within the Caribbean region, when a large part of Chiapas was under the sea after the Cretaceous-Tertiary mass extinction event. This finding also provides evidences suggesting the membership of Aulostomoidea within the order Gasterosteiformes, in which the scutes covering the trunk and the robust spines in unpaired fins are recurrent features.
\end{abstract}

Kleyton Magno Cantalice. Departamento de Paleontología, Instituto de Geología, Universidad Nacional Autónoma de México; Circuito de la Investigación, Ciudad Universitaria, Coyoacán, Ciudad de México, 04510, México. kleytonbio@yahoo.com.br

Jesús Alvarado-Ortega. Departamento de Paleontología, Instituto de Geología, Universidad Nacional Autónoma de México; Circuito de la Investigación, Ciudad Universitaria, Coyoacán, Ciudad de México, 04510, México. alvarado@geologia.unam.mx

Keywords: new species; Aulostomoidea; fossil; Paleocene; Chiapas; Mexico

Submission: 13 May 2016 Acceptance: 10 October 2016

http://zoobank.org/F82FD739-14B2-4736-82DA-445FE7477A59

Cantalice, Kleyton Magno and Alvarado-Ortega, Jesús. 2016. Eekaulostomus cuevasae gen. and sp. nov., an ancient armored trumpetfish (Aulostomoidea) from Danian (Paleocene) marine deposits of Belisario Domínguez, Chiapas, southeastern Mexico. Palaeontologia Electronica 19.3.53A: 1-24

palaeo-electronica.org/content/2016/1659-ancient-armored-trumpetfish

Copyright: @ December 2016 Society of Vertebrate Paleontology. This is an open access article distributed under the terms of the Creative Commons Attribution License, which permits unrestricted use, distribution, and reproduction in any medium, provided the original author and source are credited.

creativecommons.org/licenses/by/4.0/ 


\section{INTRODUCTION}

The superfamily Aulostomoidea is a highly specialized group of marine acanthomorph fishes (Greenwood et al., 1966), which are widely distributed along the tropical and subtropical seas (Wheeler, 1955; Fritzsche, 1976, 1981; Eschmeyer et al., 2016; Froese and Pauly, 2016). Living aulostomoids are gathered in two families, two genera, and seven species (Nelson et al., 2016); the family Aulostomidae, commonly named as trumpetfishes, includes three species of the genus Aulostomus Lacépède, 1803, while the four species of the genus Fistularia Linnaeus, 1758, represent the family Fistulariidae, also commonly known as cornetfishes.

According to the prevalent classification that includes the aulostomoids that are based on morphological data (Keivany and Nelson, 2006); Aulostomidae, Fistulariidae, and another nine families with living species constitute the order Gasterosteiformes. The fossil records of aulostomoids have been scarce; however, these point out that in the past this superfamily was much more diverse (e.g., Kner and Steindachner, 1863; Blot, 1980; Bannikov, 1993, 2014; Carnevale et al., 2014; among others) including other taxa as: 1) The family Urosphenidae (Gill, 1884) that probably incorporates three species of the genus Urosphen Agassiz, 1842 [U. fistularis Agassiz, 1842; U. dubius (Blainville, 1818), and U. attenuata Eastman, 1914], Urosphenopsis sagitta Danil'chenko, 1968, as well as Oligosphenopsis gracilis Parin, 1992. 2) Two families named by Blot (1980), the monospecific Parasynarcualidae represented by Parasynarcualis longirostris (Blainville, 1818) plus the Fistularioididae, in which two species described by Blot (1980) are included, Fistularioides veronensis and F. phyllolepis, as well as Pseudosyngnathus opisthopterus (Agassiz, 1833). 3) Additional extinct members of the family Aulostomidae, as Aulostomus medius Weiler, 1920; A. fractus Danil'chenko, 1960a; Eoaulostomus bolcensis (Blainville, 1818) and E. gracilis Blot, 1980; Synhypuralis jungerseni, Blot, 1980; S. banisteri Blot, 1980; Jungensenichthys elongatus Blot, 1980; Macroaulostomus veronensis Blot, 1980; Tyleria necopinata Parin, 1993; and Frauenweilerstomus synarcualis Parin and Micklich, 1996a. 4) The incertae sedis species Aulostomoides tyleri Blot, 1980. 5) Extinct species of Fistularia, including F. koenigi Agassiz, 1842; F. licatae Sauvage, 1880; F. contermina Danil'chenko, 1960b; and Fistularia sp. (Girone et al., 2010; Pictet et al., 2013; among others).
Besides, increasingly molecular phylogenetic studies have been explored the relationships of Aulostomoidea and other acanthomorphs, resulting in important alternative hypotheses (Wilson and Orr, 2011; Near et al., 2012, 2013; Betancur-R et al., 2013a, 2013b, 2015; Song et al., 2014), in which this superfamily is an unnatural group, and its families Fistulariidae and Aulostomidae are placed apart as members of the order Syngnathiformes that also includes the Mullidae, Callionymidae, Draconnettidae, and Dactylopteridae. Today, there is no consensus on this topic because results of the different molecular approaches are comparatively inconsistent and contradictory (Chen et al., 2003, 2014; Smith and Wheeler, 2004; Dettai and Lecointre, 2005; Kawahara et al., 2008; Li et al., 2009; among others).

The sisterhood relationship between fustulariids and aulostomids into the suborder Aulostomoidea and order Gasterosteiformes has been maintained for a long time (e.g., Cuvier, 1816; Gill, 1872; Regan, 1909; Jungersen, 1910; Berg, 1940; Wheeler, 1955; Greenwood et al., 1966; Pietsch, 1978; Fritzsche, 1981; Johnson and Patterson, 1993; Orr, 1995; Nelson, 2006; Nelson et al., 2016; among others). Unfortunately, a recent phylogenetic study on Gasterosteiformes, purely based on morphological data of living species, shows that this relationship is weak because it is based on a combination of homoplasies, including characters independently developed in other gasterosteiforms (Keivany and Nelson, 2006).

Morphological characters preserved in the fossils are useful to understand the origin, early diversification, and the multiple elusive details along the evolutionary history of problematic taxa. Up to now, phylogenetic studies have not exploited the huge potential data preserved in the fossils related to Aulostomoidea, which are known mainly from Eocene (56-34 Ma) and Oligocene (34-23 Ma) marine sediments along Europe, and exposed in Germany, France, Denmark, and the emblematic Italian Lagersttäte site of Monte Bolca (Zigno, 1887; Blot, 1980; Micklich, 1998; Pharisat and Micklich, 1998; Bonde et al., 2008; among others).

In 2008, the Instituto Nacional de Antropología e Historia (INAH) and the Universidad Nacional Autónoma de México (UNAM) launched a paleontological-archaeological joint project to collect and identify the fossils associated to the archaeological Maya city of Palenque. One of the successes achieved during the summer 2014 in this project was the discovery of a peculiar, complete, and well-preserved aulostomoid fish in the 
Belisario Domínguez quarry (Figure 1). This newly paleontological site of difficult access is a small outcrop of Paleocene (Danian age, 63Ma) marine sediments, which is located $9.5 \mathrm{~km}$ south of Palenque town and about $2 \mathrm{~km}$ north from the homonymous village, into the State of Chiapas, southeastern México (Alvarado-Ortega et al., 2015). Currently, the strata already exploited in this quarry hardly exceed the soil level; however, this has proven to be a promising fossiliferous site. In this quarry, the fossil bearing strata consists of marine parallel laminated marls and limestones that belong to the Tenejapa-Lacandón geological unit. The División del Norte quarry is another small quarry near Palenque that bears similar fossils on strata that also belong to this geological unit. The fish assemblage recovered in these quarries includes eels, herrings, pycnodonts, "serranids", osteoglossids, gonorynchiforms, and other still unidentified teleostean fishes (Cuevas-García and Alvarado-Ortega, 2008, 2009; Alaniz-Galvan, 2011; Alaniz-Galvan and Alvarado-Ortega, 2011; Solano-Templos and Alvarado-Ortega, 2013; Alvarado-Ortega et al., 2015; Than-Marchese et al., 2015).

The aim of the present paper is to provide an accurate anatomical description of the single aulostomoid fish recovered in the Belisario Domínguez quarry. Additionally, the inclusion of this Mexican specimen into an updated phylogenetic analysis reveals the singularity of this entirely armored fish among the superfamily and supports its designation as a new genus and species.

\section{MATERIAL AND METHODS}

Institutional abbreviations. The referred specimen is housed in the Colección Nacional de Paleontología. This is incorporated into the Instituto de Geología (previously Instituto Geológico de Méx$i c o$, whose acronym is IGM), with address in the main campus (Ciudad Universitaria) of the Universidad Nacional Autónoma de México. The specimen is cataloged under the number IGM 4716.

Anatomical nomenclature and abbreviations. Osteological nomenclature and abbreviations used in this paper follow previous anatomical studies (e.g., Regan, 1909; Fritzsche, 1976, 1981; Pharisat and Micklich, 1998; Keivany and Nelson, 2006).

Preparation. The single specimen studied here was discovered in summer of 2014. Given its conservation mode, it is possible to ensure that this fossil was preserved in part and counterpart; however, when it was found by the survey team, we only collected the part. Apparently, its counterpart

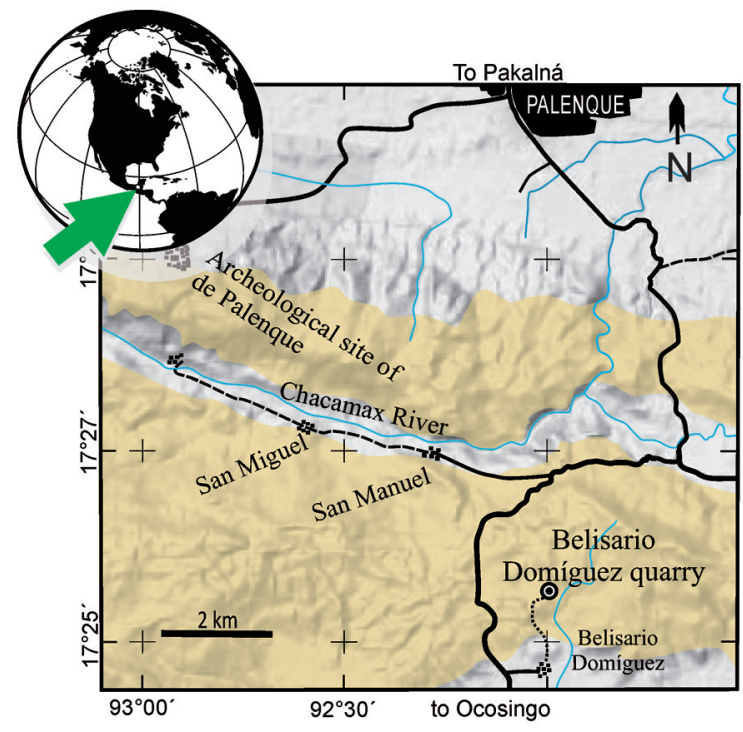

FIGURE 1. Map of the Belisario Domínguez quarry, near Palenque, Chiapas, southeastern Mexico. Yellow areas into the map show the Paleocene TenejapaLacadón geological unit.

was lost by the quarry-worker. In the rescued part, the fossil shows a large number of broken bones and a lot of its scutes expose their inner surfaces. When it was collected, the skeleton of this fish was almost totally exposed; hence, just a little mechanical preparation was necessary. Thin excavators and needles were used to remove small patches of sediments from small areas of the snout, tails, and trunk. Besides its beauty, the specimen is so wellpreserved that it was not necessary to apply any hardening substance to maintain its integrity and stability.

Phylogenetic analysis. The relationships and classification of the new fossil fish named in this work are supported in a phylogenetic analysis, which is based on a previous similar work published by Keivany and Nelson (2006). Their data matrix is updated in the present analysis, including the fish described herein and three additional characters not previously considered (111-113 in Appendices 1-3). In the new data matrix, two states of characters are corrected in Aulostomidae; the first is related with the existence of spines in the dorsal fin (character 88), which in this family changes from 0 (absent) to 1 (present); the second is related with the number of spines in the anal fin (character 91) that changes from 2 (absent) to 0 (more than one). The thin and elongated spines in both dorsal and anal fins are remarkable aulostomid diagnostic characters (Wheeler, 1955; Nelson 
et al., 2016). The resulting data matrix consists of 15 taxa and 113 characters; it was captured in the software NEXUS Data Editor v.0.5.0 (Page, 2001); in this work this matrix is provided in txt and NEXUS formats (Appendices 2 and 3).

A parsimony analyses under branch and bound search was performed with the software PaupUp v.1.0.3.1 (Calendini and Martin, 2005), a graphic interface of Paup v.4.0b10 (Swofford, 2002). All characters included in this essay are morphological, equally weighted, and treated as unordered; multistate characters where treated as polymorphism. Missing or not-observed characters are considered as unknown (?). The distribution of supporting characters along the resulting trees is optimized with ACCTRAN criteria. The consistency of the resulting trees is evaluated through a bootstrap analysis (Felsenstein, 1985) with 100.000 repetitions.

\section{RESULTS}

\section{Systematic Paleontology}

Superfamily AULOSTOMOIDEA sensu Greenwood et al., 1966

Family EEKAULOSTOMIDAE fam. nov. Genus EEKAULOSTOMUS gen. nov. zoobank.org/753D46C9-DB3D-4237-87BC-B8471A5A0107
Type species. Eekaulostomus cuevasae sp. nov., see below.

Derivation of name. The genus name includes the Mayan word "Eek" (= star), the Greek word "aulos" (= aủ ós, that is the name of an ancient flute), and the Latin word "stoma" (= mouth). The name refers to a "fish with a star-like scutes and flute-shaped mouth."

Diagnosis. As in the type species, see below.

Eekaulostomus cuevasae sp. nov.

zoobank.org/FE49A9FD-EE5C-4FCA-9556-04DD13138E79

Holotype. IGM 4716, almost complete specimen exposing the right lateral side of the body (Figures 2-5).

Derivation of name. The specific epithet of this fish honors our colleague, Martha Cuevas García, whose dedication and newly passion for the fossils led us to find the only specimen of Eekaulostomus cuevasae.

Occurrence. Paleocene (Danian, $\approx 63 \mathrm{Ma}$ ) marine strata of the Tenejapa-Lacandón geological unit. Belisario Domínguez quarry, Salto de Agua Municipality, State of Chiapas, southeastern Mexico (Alvarado-Ortega et al., 2015).

Diagnosis. Aulostomoidea fish with rigid star-like scutes covering the whole trunk and part of the snout; pelvic fin placed anteriorly, just behind the
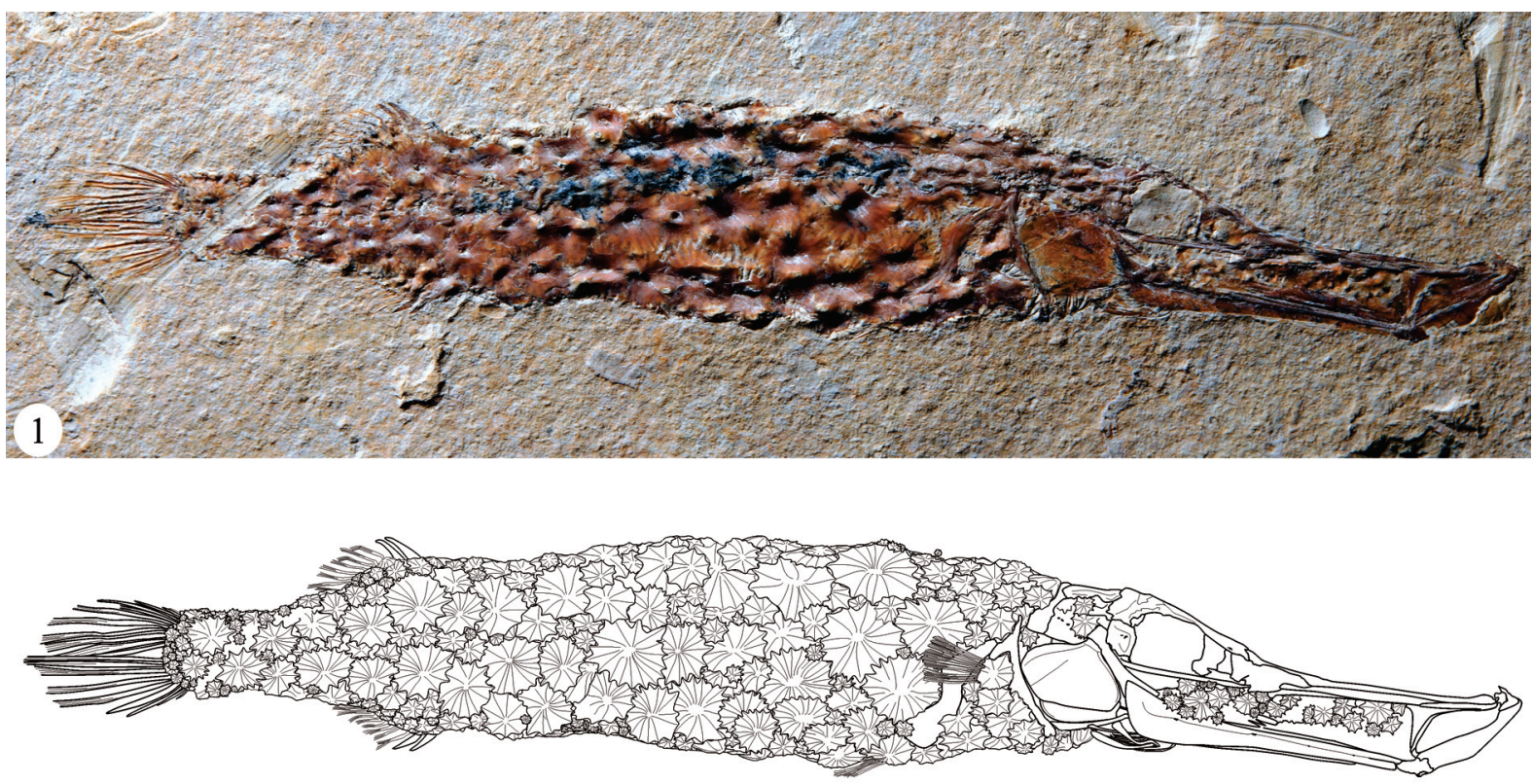

2

$5 \mathrm{~mm}$

FIGURE 2. Eekaulostomus cuevasae gen. and sp. nov. from the Danian marine deposits of the Belisario Domínguez quarry, near Palenque, Chiapas, southeastern Mexico. 1, General view of IGM 4716, holotype and single specimen known. 2, Idealized line drawing of the same specimen. 

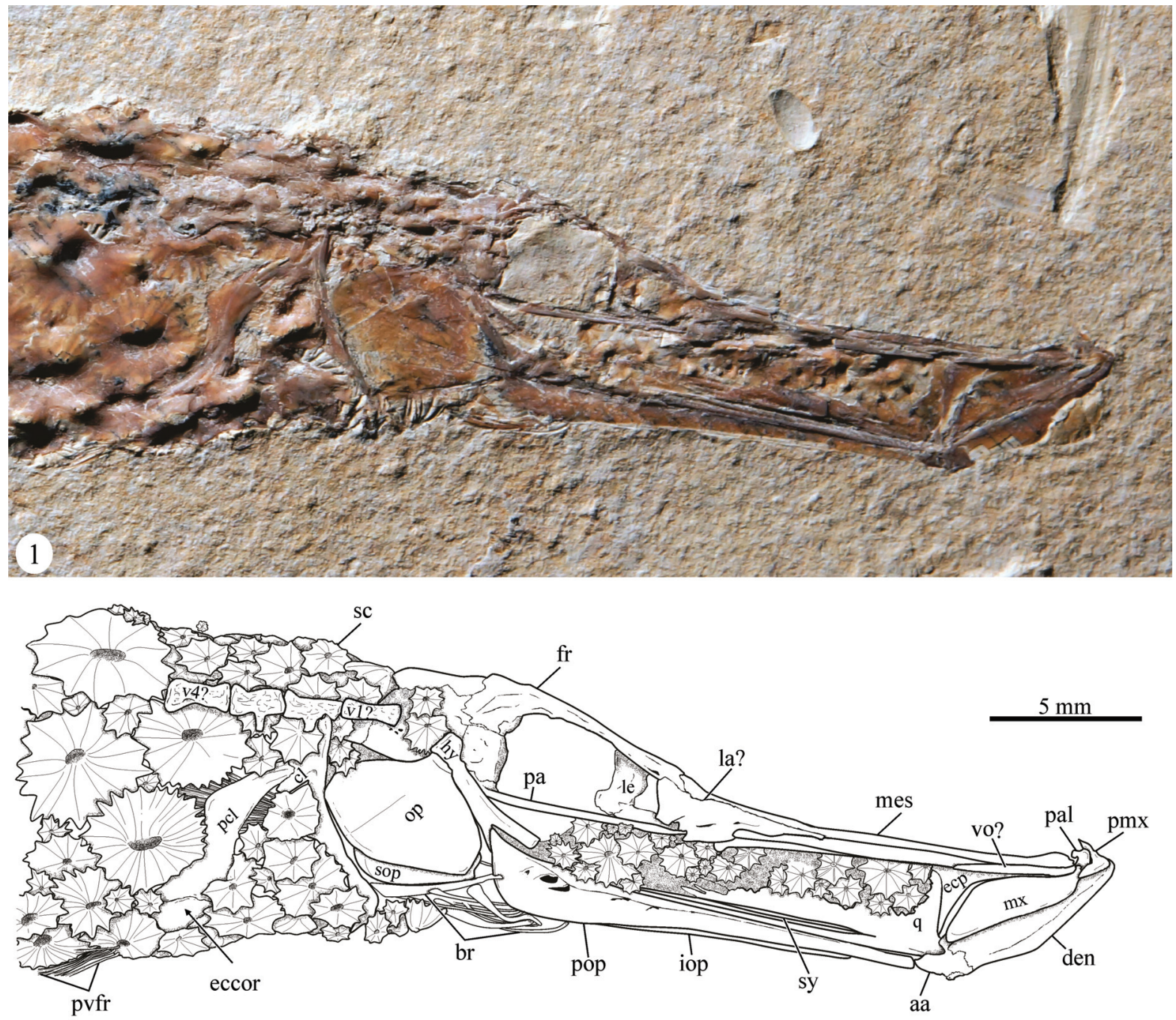

2

FIGURE 3. Head and anterior part of the trunk of Eekaulostomus cuevasae gen. and sp. nov. from the Belisario Domínguez quarry. 1, General view of the head of specimen IGM 4716. 2, Line drawing of 1. Abbreviations: aa, anguloarticular; br, branchiostegals; cl, cleithrum; den, dentary; eccor, ectocoracoid; ecp, ectopterygoid; fr, frontal; hy, hyomandibula; iop, interopercle; la, lachrymal; le, lateral ethmoid; mes, mesethmoid; mx, maxilla; op, opercle; pa, parasphenoid; pal, palatine; pmx, premaxilla; pop, preopercle; pvfr, pelvic fin rays; q, quadrate; sc, scutes; sop, subopercle; sy, symplectic; v, vertebral centra; vo, vomer (the rays of pelvic fin are seen below the cleithrum).

postcleithrum; two spines in front of the soft rays of dorsal and anal fins; eight soft rays in both anal and dorsal fins; caudal fin formula iv $+1+7-5+1+$ iii.

\section{Description}

Body shape. Table 1 summarizes the body measurements and proportion of IGM 4716. This specimen has 81.23 and $76.64 \mathrm{~mm}$ of total length (TL) and standard length (SL), respectively. In this elongated fish, the trunk is somewhat chubby because the maximum height of the body is located in the middle of the abdominal region, where it reaches $17.42 \%$ of SL, from this point the body height slightly decreases forward and backward. The caudal peduncle is relatively stout and represents almost $50 \%$ of the maximum body height. The head occupies $39.11 \%$ of SL; however, its preorbital region forms a tube that is twice as long as the rest of the head, which ends with a small mouth opening.

Both anal and dorsal fins are triangular and located far in the back of the trunk. There is just one small dorsal fin lying along the section between 80.88 and $88.36 \%$ of the SL. The anal fin is almost totally opposed to dorsal fin and occupies the section between 78.31 and $85.29 \%$ of SL. 

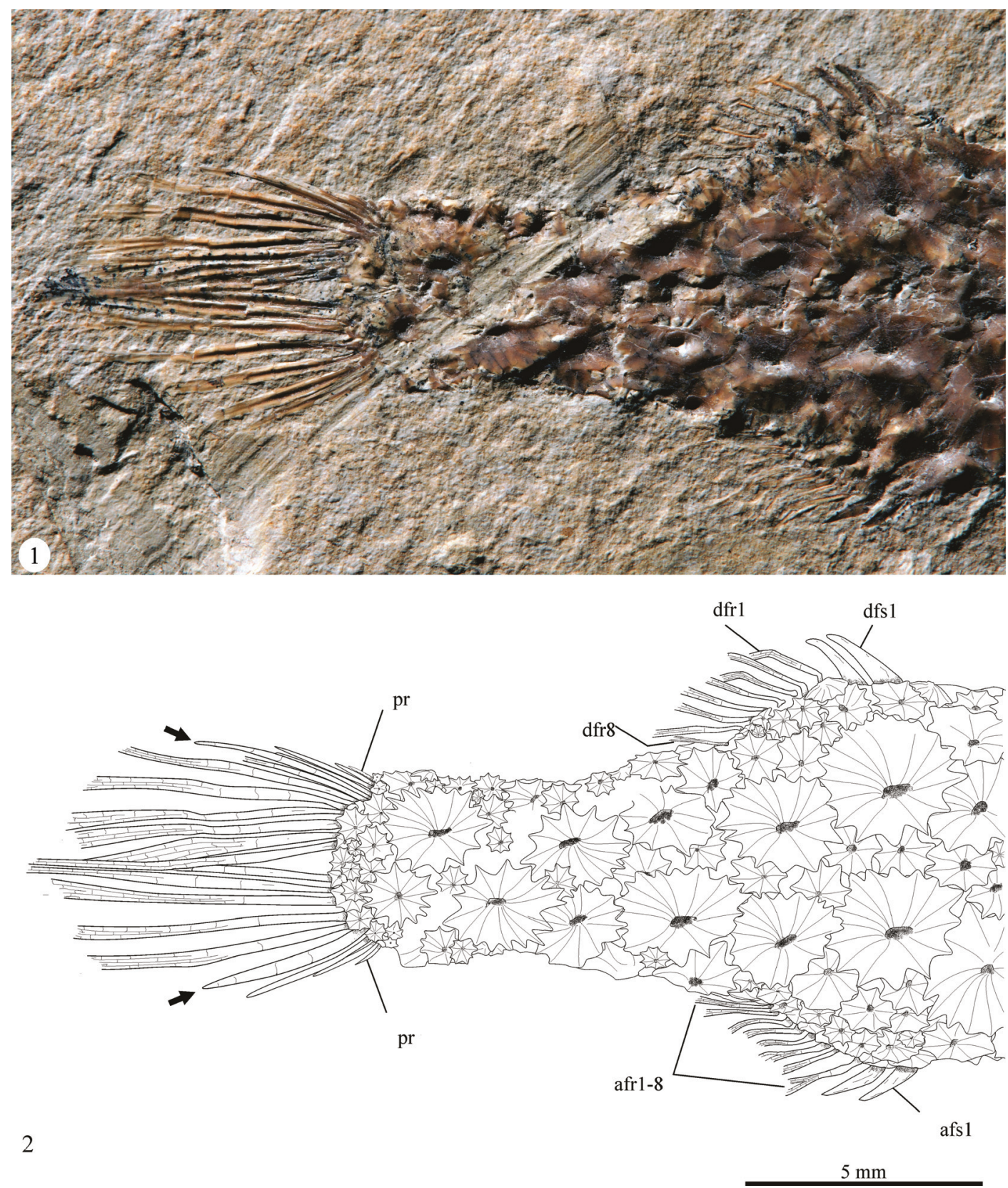

FIGURE 4. Unpaired and caudal fins of Eekaulostomus cuevasae gen. and sp. nov. from the Belisario Domínguez quarry. 1, General view of the head of specimen IGM 4716. 2, Idealized line drawing of 1. Abbreviations: afs, anal fin spines; afr, anal fin rays; dfr, dorsal fin rays; dfs, dorsal fin spines; pr, procurrent rays; black arrows enclose the principal rays of caudal fin.

Although the shape of paired fins is unknown, their rays show their position. The pelvic fin rises just below of middle height of body behind the head. The pelvic fins are ahead in the anterior half of the body, at $46.02 \%$ of SL. The caudal fin is a small, short, and semicircular structure, whose height hardly exceeds the height of the caudal peduncle. Robust scutes of serrated margins and radiating ridges cover the whole body and the postorbital and preorbital regions of the head.
The skull. Among the regions of the skull, the preorbital and orbital are equal in length, and each represents less than one quarter of the skull length. Therefore, the preorbital region occupies little more than one half of the skull length. No circumorbitals bones are present around the orbit.

Poor morphological information is rescued from the postorbital skull region of IGM 4716 because this is largely covered by scutes and the sutures between the bones are not well-defined. 

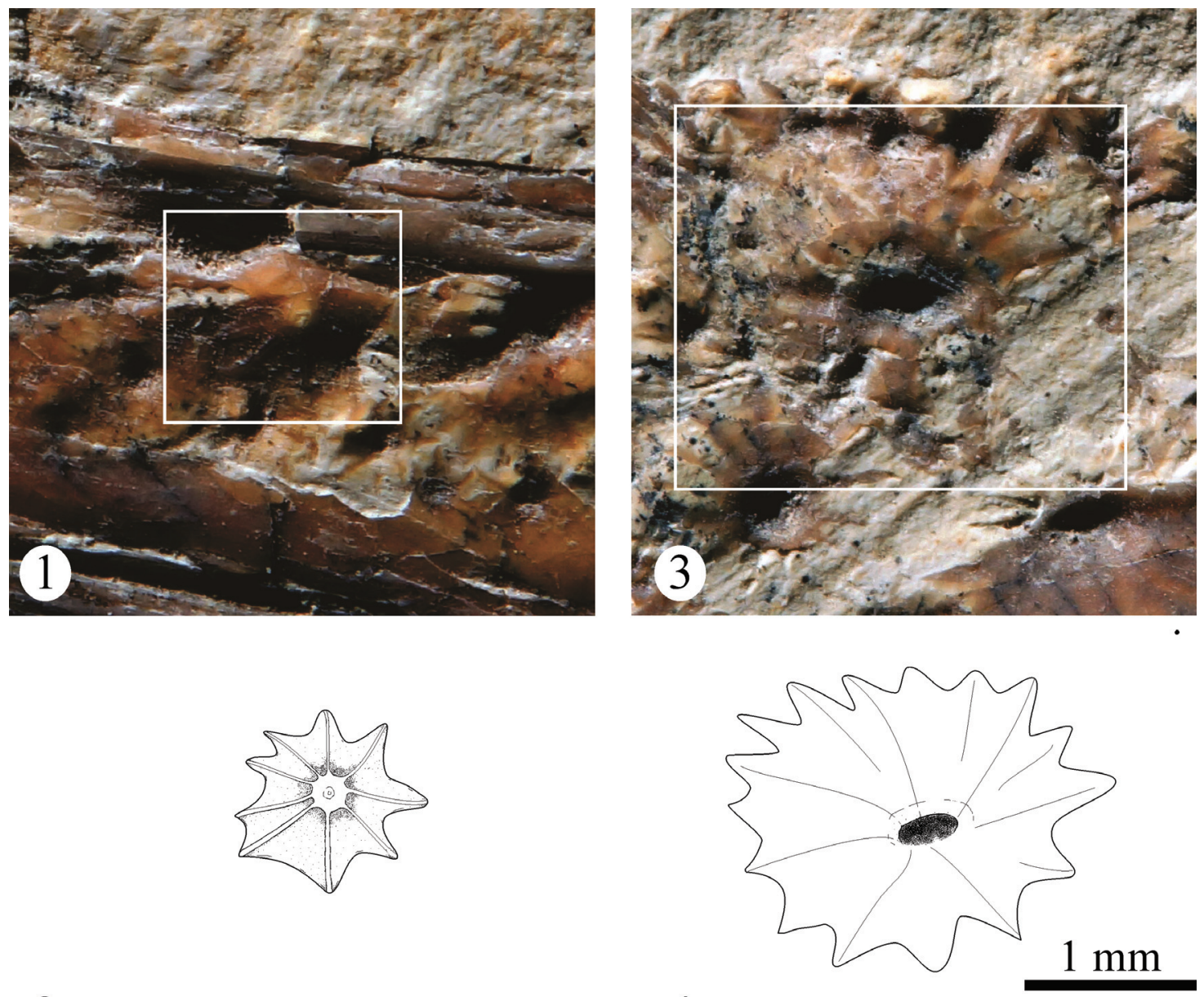

2

4

FIGURE 5. Scutes of Eekaulostomus cuevasae gen. and sp. nov. from the Belisario Domínguez quarry. 1, Close-up of the head of specimen IGM 4716, showing a scute with the external surface exposed. 2, Idealized line drawing of 1. 3 , Close-up of the caudal region of the specimen IGM 4716, showing a scute with the internal surface exposed.

The preorbital region is partially roofed by the frontals, which are anteriorly extended beyond to joint with the mesehtmoid bones, and does not meet the parasphenoid. The supraorbital canal extends along the frontals and opens in elongated porous. The pterosphenoid is present and occupies the region posterior ventral of the orbit; its orbital region is a toothless straight bar that cross the ventral section of the orbit and is extended beyond probably between the lateral ethmoids. The vomer is jointed to the anterior ventral surface of the mesethmoid.

The mesethmoid is an extremely elongated bone that partially roofs the preorbital region of the skull, reaching the anterior tip of the skull. The lateral ethmoid (= prefrontal of Jungersen, 1910; Gregory, 1959) is a stout rectangular bone between the frontals and parasphenoid forming the anterior limit of the orbit and the posterior limit of the nasal capsule.

Jaws. The mouth opening in IGM 4716 is small and tilted upward. The jaws are small and occupy the anterior third of the preorbital region. In this fish, the premaxilla and maxilla are well-preserved showing its natural inclined position. The premaxilla is an inverted L-shaped bone; in which the vertical limb is a well-developed anterior ascending process while the horizontal limb is an edentulous rod. This maxilla is an expanded, ovoid, and edentulous bone, four times longer than the premaxilla. Its dorsal border is gently curved whereas its ventral border is practically straight. The articular head of the maxilla is tiny. There are no supramaxillae bones.

The dentary is the larger bone in the lower jaw, in which it occupies the anterior $80 \%$ of this organ. Dentary is somewhat triangular shaped 
TABLE 1. Measurements and body proportions of IGM 4716, holotype and single specimen known of Eekaulostomus cuevasae gen. and sp. nov.

\begin{tabular}{lcc}
\hline & \multicolumn{2}{c}{ Measurements } \\
& in $\mathbf{~ m m}$ & as \% of SL \\
\hline Total length & 79.64 & - \\
Standard length (SL) & 72.76 & - \\
Head length & 26.73 & 36.73 \\
Postorbital length & 51.50 & 70.78 \\
Orbital length & 3.95 & 5.42 \\
Preorbital length & 17.17 & 23.59 \\
Prepelvic length & 33.49 & 46.02 \\
Predorsal length & 58.85 & 80.88 \\
Dorsal fin length & 5.44 & 7.48 \\
Preanal length & 56.98 & 78.31 \\
Anal fin length & 5.01 & 6.88 \\
Head height & 8.51 & 11.69 \\
Maximum body height & 12.14 & 16.68 \\
Caudal peduncle height & 5.02 & 6.89 \\
Postdorsal length & 7.15 & 9.83 \\
Postanal length & 9.33 & 12.82 \\
\hline
\end{tabular}

because its symphysis is shallow in comparison with its rear. The ventral edge of this bone is slightly curved. Although the alveolar border of dentary is totally covered below the maxilla; probably, it is a toothless bone too. The posterior part of the lower jaw is occupied by the anguloarticular bone, which posteriorly forms a stout articular process; it is firmly sutured with the dentary. The mandibular sensory canal is extended within a longitudinal ridge alongside the ventral border of these bones, where it opens in small pores.

Hyopalatine bones. In IGM 4716, the anterior bones of the hyopalatine series are elongated and form part of the pipe-shaped preorbital region of the head. In this fossil, such bones are broken and expose their labial surfaces. The hyomandibular is ax shaped, in which the handle is tilted and extended from the middle part the orbit up to the postorbital region of the skull. This bone has a broad, single, articulatory head. The metapterygoid and entopterygoid are almost totally covered.

The quadrate is the longest bone in the hyopalatine series but it not as long as preopercle; its triangular shape forms a high dorsal flange that occupies the posterior two thirds of the preorbital region of the skull. The condyle of the quadrate is anteriorly tilted and its articulation with the lower jaw lies far from the orbit. The sympletic is elongated spine like bone inserted on the rear of the quadrate. The entopterygoid lies totally in front of the quadrate; its shape is an $L$ upside down. The palatine lies in the dorsal anterior half of the entopterygoid; this is an elongate bone with a stout rounded anterior process. The palatine bones are edentulous.

Opercular series. Undoubtedly, the opercle, subopercle, preopercle, and interopercle are present in IGM 4716. All of them are laminated, thin, and smooth bones. The opercle is kidney shaped, 1.3 times longer than high. In this bone, the hyomandibular facet is located in its anterior dorsal corner. The subopercle is under opercle; it has a concave ventral edge and a short anterior ascending process.

In this series, the preopercle is the most remarkable bone because its horizontal $\operatorname{limb}$ is extremely elongated; it is four times longer than high. The preopercular sensory canal opens into four pores and probably one or two located along the preopercular horizontal and vertical limbs, respectively. In IGM 4716, the elongated interopercle is almost totally covered by the preopercle and seems to have no posteroventral expansion.

Vertebral column. Given its preservation mode, the axial skeleton of IGM 4716 is almost totally lost; however, some incomplete and strongly distorted vertebral centra are preserved behind the occiput. These are elongated structures, at least three times longer than high, which seem to be somewhat cylindrical with no process or neural arches preserved.

Paired fins and girdles. Bones of the pectoral girdle are largely obscured by scutes. The cleithrum is an elongated, thin, smooth bone that is tilted down and forward; its height is about two thirds the height of the trunk. On its medial region, this bone has an expansion to suture with the coracoid. A conspicuous single postcleithrum is present; this laterally sigmoid bone is almost as high as the cleithrum. Although, a large part of the ectocoracoid is under the scutes and its joint with the cleithrum is obscured, the posterior part of this elongated bone is exposed showing that it reaches the level of the posterior ventral tip of the postcleithrum (Figure 3).

The pectoral fin is somewhat rectangular because its base seems to be vertical and high. Fourteen thin and branched pectoral rays, extended backward being as long as the postcleithrum, form part of this fin. The pectoral fin is located behind the cleithrum, near to the middle of the height of the trunk. 
Although the pelvic bones are totally obscured by scutes; six thin branched and segmented fin rays show the position of the pelvic girdle. These rays rise near to the end of the first half of SL, on the abdominal edge of the trunk, and just behind the posterior ventral end of the postcleithrum (Figure 2).

Unpaired fins. The single dorsal and the anal fins are small and triangular, practically opposed to each other, and located far back in the body. The lengths of the dorsal and anal fins represent 7.48 and $6.88 \%$ of SL, respectively. Dorsal fin comprises two short stout spines and eight branched and segmented soft rays. This composition is similar to that of the anal fin; however, the anal rays are more closely located to each other. Bones of the internal support of these fins are not preserved.

Caudal skeleton. Supporting bones of the caudal fin are covered by the scutes. The caudal fin is shallow, rounded, and their elements are ordered according the to formula iv $+|+7-5+|+$ iii. On the one hand, four unbranched and unsegmented procurrent rays precede the upper caudal fin lobe, which also consists of one unbranched plus seven branched and segmented principal rays. On the other hand, there are three procurrent rays in front of the lower caudal fin lobe, which includes one unbranched plus five branched and segmented principal rays. In both caudal fin lobes, the principal rays tend to be longer toward the middle line; hence, the longest rays are in the middle of this fin, where they are in horizontal position and parallel to each other (Figure 4).

Scutes. Thick scutes randomly distributed are covering the whole trunk and part of the postorbital and preorbital regions of the head (Figures 2-5). These are star-like scutes, whose general shape is circular or ovoid with borders entirely occupied with serrations. Such serrations are more conspicuous and less numerous in the small scutes while these tend to be shallower and more abundant in the larger scutes (Figure 5). Although it is hard to recognize a pattern on the distribution of these scutes; along the trunk, the larger are distributed longitudinally on the flanks, behind the pectoral girdle while the small scutes are located on the occiput, head, around the fin bases, and along the dorsal and ventral edges of the trunk.

Some scutes on the preorbital region and middle part of the body expose their external surface. In these scutes, strong radiating ridges are projected from a prominent central tubercle up to the tip of each serration on the edge (Figures 5.1, 5.2). Given the conservation mode of IGM 4716, almost all its scutes show the inner surface, which is entirely smooth and has a central depression that corresponds with the thick central tubercle on the external surface of each scute (Figures 5.3, 5.4). In IGM 4716, some of those scutes that expose their external surfaces have a small central pore on the tip of the tubercle; however, these are so scattered that it is not possible to describe the lateral line way along the trunk.

Remarks. According Nelson et al. (2016, p. 409), the families Aulostomidae and Fistulariidae constitute the superfamily Aulostomoidea, as firstly recognized by Greenwood et al. (1966). In the most recent of these works, this superfamily is supported based on three shared characters: 1) The first four vertebrae elongated; 2) the pelvic fin consists of six (or rarely five) soft rays; and 3 ) the presence of three nuchal plates (median dorsal bony plates located behind the occiput). It is remarkable that the general details of the body of Eekaulostomus cuevasae gen. and sp. nov. resemble those of the aulostomoids or trumpetfishes; however, the inclusion of this Mexican species as an indubitable member of this superfamily obeys to the presence of the first two of these characters (Figure 3).

Nelson et al. (2016) also noted some distinctive characters of Aulostomidae and Fistulariidae; the comparison of these characters with those here discovered in Eekaulostomus cuevasae gen. and sp. nov. reveals that this new fish does not belong to any of these families. On the one side, in aulostomids the body is covered with small scales; the dorsal fin consists of eight to nine thin and elongated dorsal fin spines plus 22 to 27 soft fins; the anal fin only includes 23 to 28 soft rays, and the caudal fin is rounded. On the another side, in fistulariids the body is naked or is covered with tiny prickles (spinules sensu Fritzsche, 1981) and linear scutes; both unpaired fins have no spines and are relatively shorter because they only consist of 13 to 20 soft rays; and the caudal fin is forked and has a middle caudal filament formed by two inner elongated caudal rays. Although the caudal fin of Eekaulostomus cuevasae gen. and sp. nov. is rounded as that of the aulostomids; the fins and body coverage of this new Mexican fish display different contrasting conditions; its whole body and part of its head are covered with star-like scutes while its unpaired fins have only two stout spines and less soft rays (only eight in both fins) (Figures 2, 4). The comparison of Eekaulostomus cuevasae gen. and sp. nov. and other fossil taxa already related with the superfamily Aulostomoidea also shows the singularity of this new species. Mem- 
bers of Urosphenidae, Parasynarcualidae, and Fistularioididae do not have anal fin spines, and their bodies are shallow and extremely elongated, conditions that strongly contrast with the presence of spines in both the unpaired fins and the elongated chubby body noted in E. cuevasae. The body armored coverage of $E$. cuevasae also differs from other extinct aulostomoids, where it is common to find bodies naked or covered with small scales.

The presence of covering scutes among aulostomoids is not a new finding. Previously, Bonde (1997) reported a Danish unnamed armored aulostomoid and Parin and Micklich (1996) named Aulostomus medius that has a body covered with rows of rectangular and evenly sized scales. Again, a glace to these fossils proves the singularity of $E$. cuevasae. In the first case, the Bonde's fish has not yet been neither accurately described nor formally named, and therefore, it is impossible to carry out a fruitful comparison. In the second case, the scales of $A$. medius are rectangular, evenly small sized, and ordered in rows, which are deeply different to the unordered star-like scutes of different size found in $E$. cuevasae.

Considering the context described on the two anterior paragraphs, in this work we named a new family, Eekaulostomidae, to include the species Eekaulostomus cuevasae gen. and sp. nov. The relationships of this Mexican fossil fish and other members of the superfamily Aulostomoidea are explored in the phylogenetic analysis described ahead.

\section{Phylogenetic Analysis}

In the present research we performed two phylogenetic analyses following the same protocols. Initially we use the data matrix and procedures considered by Keivany and Nelson (2006, figures 1,2 ) trying to recover their result. Although we recovered the same and single most parsimonious tree of these authors; the supporting characters of nodes in our first analysis are different (see the comparison in Table 2).

Subsequently, we added Eekaulostomus cuevasae gen. and sp. nov. and the corrections previously described into an updated data matrix. We use this data to perform the second analysis. Although the single and most parsimonious tree recovered in this second study is practically the same generated by Keivany and Nelson (2006, figures 1,2) and our first analysis, except for the inclusion of Eekaulostomus as the sister group of the unnamed clade including Aulostomidae and Fistulariidae (node $\mathrm{J}$ in Figure 6). These resulting trees show differences in the distribution of supporting characters (synapomorphies and homoplasies), as it is summarized in Table 2.

The single parsimonious tree including Eekaulostomus cuevasae gen. and sp. nov. obtained in the present study (Figure 6) has 279 steps of length, consistency index of 0.43 ; retention index of 0.55 , and homoplasy index of 0.57 . Results of the bootstrap analysis performed in this study support the topology of our tree (Figure 6), except for node $G$ that is supported in less than $50 \%$. It is remarkable the low number of synapomorphies in our result (Table 2); nevertheless, Eekaulostomus cuevasae gen. and sp. nov. is located as the sister group of Aulostomidae plus Fistulariidae, and all these together form a monophyletic group, the new sense of the superfamily Aulostomoidea (Figure 6, nodes $\mathrm{K}$ and $\mathrm{J}$ ).

The anatomy of Eekaulostomus cuevasae gen. and sp. nov. is relatively poorly known. Therefore, the data matrix of 113 characters built in the present study only includes 26 non-doubtful characters of $E$. cuevasae. Despite this situation, the present phylogenetic study provides enough information to support the inclusion of $E$. cuevasae into the suborder Syngnathoidei, infraorder Syngnathoida, and superfamily Aulostomoidea sensu Keivany and Nelson (2006, p. S90) (nodes D, F, and $\mathrm{J}$, respectively in Figure 6). The single synapomorphy of Syngnathoidei, the lack of distinctive cranial condyles in the hyomandibular (35-1), is present in Eekaulostomus that has a hyomandibular with a simple undivided articular head (Figure 3). Eekaulostomus also exhibits three of the seven synapomorphies of the infraorder Syngnathoida (node $F$ in Figure 6 and Table 2); its vomer is located superficially anteriorly (3-1), its quadrate shows a deep dorsal flange (29-1), and its interopercle is elongated (41-1) (see Figure 3).

Eekaulostomus cuevasae gen. and sp. nov. is a member of Aulostomoidea because it displays the single synapomorphy of this superfamily (clade $\mathrm{J}$ in Figure 6 and Table 2), the ectocoracoid is an elongated bone that reaches the posterior level of the postcleithrum (113-1), as well as three of its nine homoplasies [its maxillar is expanded ventrally (22-0); its quadrate articulates with the lower jaw below (33-0); and has a well-developed ectocoracoid (78-1)]. The other six homoplasies present in this superfamily (i.e. 14-0, 16-1, 22-0, 64-1, 68-1, 77-1) are unknown in Eekaulostomus cuevasae gen. and sp. nov.

Eekaulostomus cuevasae gen. and sp. nov. has two autapomorphies: the presence of stout 
TABLE 2. Comparison between results of phylogenetic analyses on Gasterosteiformes published by Keivany and Nelson (2006, figure 1), results of the same essay obtained in this work, and obtained after the inclusion of Eekaulostomus cuevasae gen. and sp. nov. and characters 111 to 113. The topology of trees in these three analyses is similar (see Figure 6) except for node J after the inclusion of E. cuevasae. Synapormorphies are underlined and characters with different positions throughout these comparisons are in bold.

\begin{tabular}{|c|c|c|c|}
\hline & $\begin{array}{l}\text { Published by Keivany } \\
\text { and Nelson (2006). } \\
308 \text { steps, } \mathrm{Cl}=0.5\end{array}$ & $\begin{array}{c}\text { Replay of Keivany and Nelson, (2006), in } \\
\text { this work. } \\
\text { 271steps, } \mathrm{Cl}=0.43\end{array}$ & $\begin{array}{c}\text { Present work. } \\
279 \text { steps; } \mathrm{Cl}=0.43\end{array}$ \\
\hline A & $\begin{array}{l}\frac{43-1}{1}, \underline{47-1}, \underline{70-1}, \underline{80-} \\
\underline{105-1}, \underline{91-2}, \underline{106-1}\end{array}$ & $\begin{array}{l}6-1,11-1,14-1,20-1,22-1,43-1,47-1,50- \\
1,60-1,63-1,70-1,82-1,87-1,90-1,91-2 \\
97-1,104-1,105-1,106-1,108-1\end{array}$ & $\begin{array}{c}6-1,11-1,14-1,20-1,22-1,43-1,47-1 \\
50-1,60-1,63-1,70-1,82-1,87-1,90- \\
1,91-2,97-1,104-1,105-1,106-1 \\
108-1\end{array}$ \\
\hline B & - & $\underline{4-1}, 27-1,31-1,75-1, \underline{80-1}, 99-1,103-1$ & \\
\hline $\mathrm{C}$ & $\frac{7-1}{78-1}, \underline{25-1}, \underline{32-1}, \underline{91-1}, \underline{41-1}$ & $\begin{array}{l}1-1,7-1,12-1, \underline{25-1}, 30-1,32-2,41-1,71-0, \\
77-1,78-1,85-1, \underline{89-1}, 91-1, \underline{92-2}\end{array}$ & $\begin{array}{l}1-1,7-1,12-1, \underline{25-1}, 30-1,32-2,41-1 \\
77-1,78-1,85-1, \underline{89-1}, 91-1, \underline{92-2}\end{array}$ \\
\hline $\mathrm{D}$ & $\underline{9-1}, \underline{19-1}, \underline{57-1}, \underline{86-1}$ & $\begin{array}{l}8-1,9-1,19-1,40-1,50-0,57-1,62-1,65-1 \\
67-1,84-1,86-1,97-0,98-1, \underline{100-1}, 108-0\end{array}$ & $\begin{array}{l}8-1,9-1,19-1,40-1,50-0,57-1,62-1 \\
65-1,67-1,84-1,86-1,97-0,98-1,100- \\
1,108-0\end{array}$ \\
\hline $\mathrm{E}$ & - & $\begin{array}{l}6-0,13-1,18-1,20-0,33-1,35-1,43-0,51- \\
1,52-1,53-1,54-1,88-1,90-0,94-1,95-1 \\
99-0,101-1\end{array}$ & $\begin{array}{l}6-0,13-1,18-1,20-0,33-1,35-1,43-0, \\
51-1,52-1,53-1,54-1,88-1,90-0,94-1, \\
95-1,99-0,101-1\end{array}$ \\
\hline $\mathrm{F}$ & $\underline{3-1}, \underline{10-1}, \underline{28-1}, \underline{29-1}$ & $\frac{3-1}{1,46-1, \underline{10-1}, 26-1}, \underline{59-2,}, \underline{28-0}, \underline{29-1}, \underline{30-1}, \underline{32-0}, \underline{41-1}, 45-$ & $\frac{3-1}{45-1}, \underline{10-1}, 26-1, \underline{58-1}, 59-2,29-1,62-0,79-1, \underline{41-1}$, \\
\hline G & $\underline{1-2}, \underline{39-1}$ & $1-2,17-1,39-1,50-1$ & \\
\hline $\mathrm{H}$ & - & $\begin{array}{l}40-0,43-1,54-0,63-0,65-0,74-1,76-1 \\
88-0,93-1,98-0,108-1\end{array}$ & $\begin{array}{l}40-0,43-1,54-0,63-0,65-0,74-1,76-1 \\
88-0 \text { 93-1, 98-0, 108-1 }\end{array}$ \\
\hline 1 & $\frac{15-1}{1,}, \underline{36-1}, \underline{96-1}, \underline{49-1}, \underline{81-}$ & $\begin{array}{l}\frac{15-1}{59-0}, 72-0,36-1,48-1,49-1,52-0,57-0 \\
88-0,96-1\end{array}$ & $\begin{array}{l}\frac{15-1}{59-0}, 72-0,36-1,48-1,49-1,52-0,57-0, \\
84-0,96-1\end{array}$ \\
\hline $\mathrm{J}$ & - & - & $\begin{array}{l}14-0,16-1,22-0,33-0,44-1,64-1,68-1, \\
77-1,78-1, \underline{113-1}\end{array}$ \\
\hline $\mathrm{K}$ & $\underline{16-1}, \underline{44-1}, \underline{64-1}, \underline{68-1}, \underline{77-1}, \underline{78-1}$ & $\begin{array}{l}14-0,16-1,22-0,33-0,44-1,64-1,68-1 \\
72-1,77-1,78-1,103-0\end{array}$ & $72-1,103-0$ \\
\hline Hypoptychidae & $\underline{13-1}, \underline{21-1}, \underline{34-1}, \underline{48-}$ & $\begin{array}{l}13-1,17-1,21-1,34-1,48-1,53-1,69-1 \\
88-1\end{array}$ & $\begin{array}{l}13-1,17-1,21-1,34-1,48-1,53-1,69-1, \\
71-1,88-1\end{array}$ \\
\hline Aulorhynchidae & - & $5-1,34-1,66-1,68-1,72-1,101-1$ & \\
\hline Gasterosteidae & - & $42-1,47-0,51-1,83-1$ & $42-1,47-0,51-1,83-1$ \\
\hline Indostomidae & $\frac{16-1}{1,}, \underline{39-1}, \underline{46-1}, \underline{76-1}, \underline{96-1}$ & $\begin{array}{l}14-0,16-1,17-1,32-0,39-1,47-0,48-1 \\
60-0,61-1,63-0,74-1,76-1,96-1\end{array}$ & $\begin{array}{l}14-0,16-1,17-1,32-0,39-1,47-0,48-1 \\
60-0,61-1,63-0,71-1,74-1,76-1,96-1\end{array}$ \\
\hline Pegasidae & $\frac{1-1}{42-1}, \underline{5-1}, \underline{12-1}, \underline{37-1}$ & $\begin{array}{l}1-1,5-1,8-0,12-1,31-0,37-1,42-1,71-0 \\
73-0,83-1,84-0,85-1\end{array}$ & $\begin{array}{l}1-1,5-1,8-0,12-1,31-0,37-1,42-1 \\
73-0,83-1,84-0,85-1\end{array}$ \\
\hline Solenostomidae & - & $\begin{array}{l}2-0,16-1,22-0,24-1,42-1,46-0,48-1,51- \\
0,67-0,71-0,72-1,73-0\end{array}$ & $\begin{array}{l}2-0,16-1,22-0,24-1,42-1,46-0,48-1 \\
51-0,67-0,72-1,73-0\end{array}$ \\
\hline Syngnathidae & - & $\begin{array}{l}6-1,7-1,36-1,38-0,44-1,45-0,49-1,62-1 \\
94-0,95-0,96-1,97-1\end{array}$ & $\begin{array}{l}6-1,7-1,36-1,38-0,44-1,45-0,49-1 \\
62-1,71-1,94-0,95-0,96-1,97-1\end{array}$ \\
\hline Eekaulostomus & - & - & $19-0,34-1,91-0,111-1, \underline{112-1}$ \\
\hline Aulostomidae & - & $\begin{array}{l}23-0,26-1,27-0,45-0,47-0,50-1,55-0 \\
66-1,67-0,101-0,104-0,105-0,106-1 \\
110-0\end{array}$ & $\begin{array}{l}23-0,26-1,27-0,45-0,47-0,50-1,55-0, \\
66-1,67-0,71-1,101-0,104-0,105-0, \\
106-1,110-0\end{array}$ \\
\hline Fistulariidae & - & $1-2,8-0,71-0,76-0,109-0$ & $1-2,8-0,76-0,88-1,109-0$ \\
\hline $\begin{array}{l}\text { Macrorhamphosid } \\
\text { ae }\end{array}$ & - & $\begin{array}{l}1-1,46-0,51-0,53-0,56-0,73-0,85-1,86- \\
0,93-0,94-0,99-1\end{array}$ & $\begin{array}{l}1-1,46-0,51-0,53-0,56-0,73-0,85-1 \\
86-0,93-0,94-0,99-1\end{array}$ \\
\hline Centriscidae & - & $8-0,61-1,97-1,98-1,104-0$ & \\
\hline
\end{tabular}




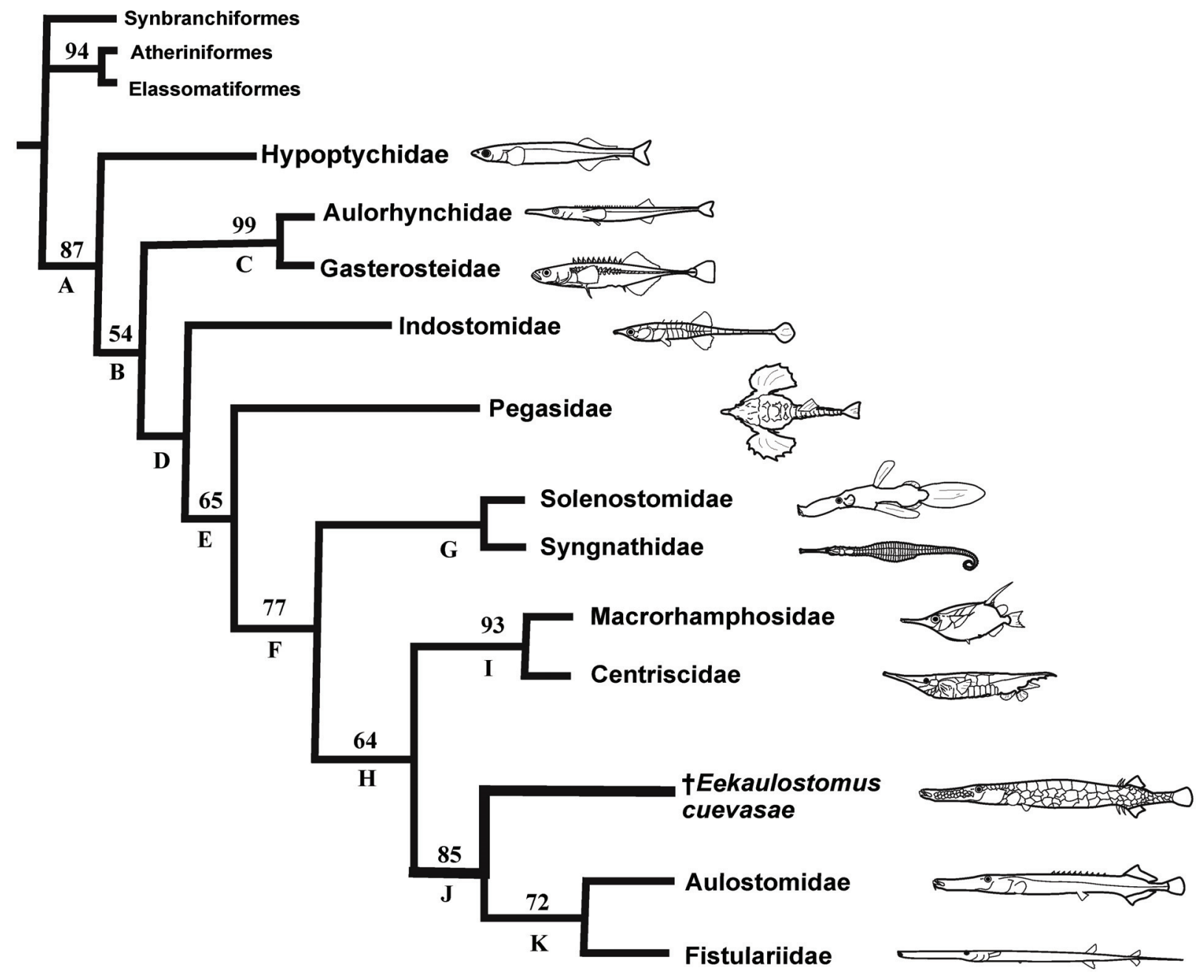

FIGURE 6. Phylogenetic relationships of Eekaulostomus cuevasae gen. and sp. nov. and the superfamily Aulostomoidea within the order Gasterosteiformes (modified from Keivany and Nelson, 2006) (check the characters supporting the nodes in Table 2; number near the nodes show the bootstrap values obtained above $50 \%$ ).

spines close together to the soft rays in both anal and dorsal fins (111-1) and scutes covering the snout (112-1); as well as three homoplasic characters not present in other aulostomoids. In this new species, the premaxillary ascending process is well developed (19-0), the hyomandibular lacks a lateral lamina (34-1), and the anal fin has more than one spine (91-0). In contrast, Aulostomidae and Fistulariidae do not have scutes or stout anal fin spines, the premaxillary ascending process is comparatively smaller, the hyomandibular shows a lateral lamina, and there are no anal fin spines; additionally, the last family neither has dorsal fin spines while the former has dorsal spines scattered and separated from each other along the dorsal border.

\section{DISCUSSION}

Wheeler (1955) predicted that the fossil record of Aulostomus in America had emerged earlier than the European species, going back even before the Eocene. Therefore, the hypothetical ancient American species should show deep morphological differences with the younger and modern species of Aulostomus. This prediction had to wait 60 years come be true. In 2014, we discover Eekaulostomus cuevasae gen. and sp. nov., into the Danian marine deposits of the Tenejapa-Lacandón geological unit, near Palenque town, a new species that in general terms resembles Aulostomus. Currently, this new species represents the oldest world record of the superfamily Aulosto- 


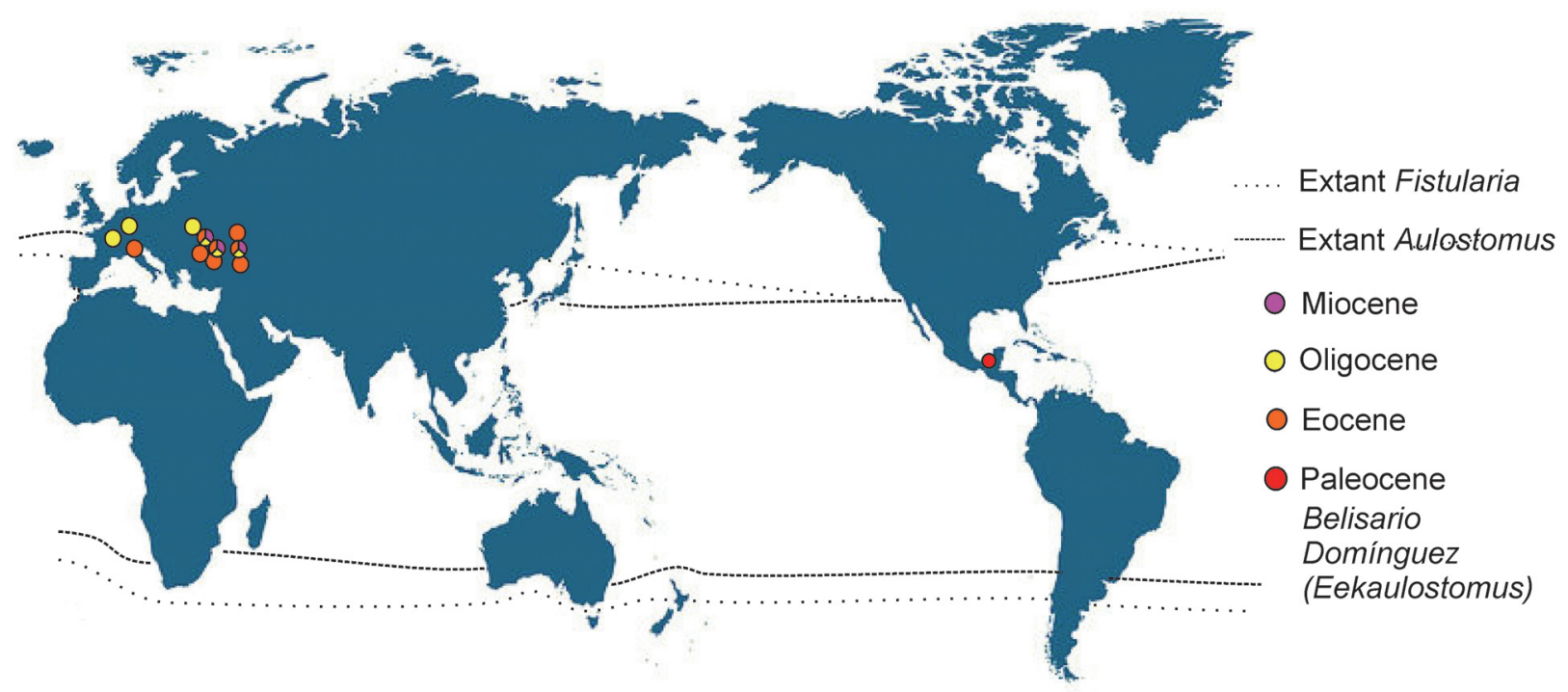

FIGURE 7. Geographical and temporal distribution of fossil and recent members of the superfamily Aulostomoidea, including Eekaulostomus cuevasae gen. and sp. nov. from the Belisario Domínguez quarry, near Palenque, Chiapas, southeastern Mexico.

moidea and the first occurrence of an Aulostomuslike fossil into the ancient tropical domains of America (Figure 7). Despite this, the morphological differences between Eekaulostomus cuevasae gen. and sp. nov. and the modern species of Aulostomus and its fossil relatives found in Europe are so deep that they have important phylogenetic implications (Figure 6) and also support the allocation of $E$. cuevasae into its own genus and family.

Recently, Betancur-R et al. (2013, fig. 4) and Near et al. (2013, fig. S1) published two large phylogenetic studies based on molecular data that include the aulostomoids. Both pointing out that the families Aulostomidae and Fistulariidae do not form a monophyletic group (= superfamily Aulostomoidea). Contrary, in these studies such families are separated from each other, being located in different positions along the phylogeny of the order Synganthiformes, where Aulostomidae occupies a more basal position than Fistulariidae. Given the impossibility to recover molecular data from Eekaulostomus cuevasae gen. and sp. nov., its discovery does not contribute in any way with these hypotheses; however, given the similarity shared of this Mexican fossil with the living and extinct species of Aulostomus, it is possible to suggest that Eekaulostomus represents an unexpected ancient branch in the aulostomid evolution.

Previous to this work, other two phylogenetic hypotheses including the living aulostomoids were published by Orr (1995) and Keivany and Nelson
(2006). These are purely based on morphological data and address relationships of the order Gasterosteiformes. Although the Orr's hypothesis resulted from his PhD studies, unfortunately it has not yet been part of a formal scientific publication; its results were reproduced into a study about the sea horse evolution (Wilson and Orr, 2011). Both essays show Aulostomoidea as a member of the suborder Syngnathoidei; however, the first author resolved that the aulostomoids represent a basal syngnathoid group, close to Centriscoidea, Pegasidae, Solenostomidae, and Syngnathidae; in contrast to the last authors, the aulostomoids are located in a derived position, as sister group of the superfamily Centriscoidea (Centriscidae plus Macrorhamphosidae). Although there are many doubts about the monophyletic nature of the order Gasterosteiformes given the weakness of morphological data used in these previous studies; today, these are unique datasets available to explore the phylogenetic relationships of Eekaulostomus cuevasae gen. and sp. nov. As already discussed, the updating of such a data matrix with the inclusion of Eekalostomus corroborates the previously obtained results (Figure 6).

Up to now, the aulostomoid fossil taxa already described are based on characters with a low phylogenetic value, such as the shape and proportions of body and head, as well as the composition of fins (Agassiz, 1833, 1842; Blainville, 1818; Weiler, 1920; Danil'chenko, 1968; Parin, 1992, 1993; Parin and Micklich, 1996a; Pictect et al., 2013; among 
TABLE 3. Morphological comparison between Eekaulostomus, and both recent and some extinct members of the superfamily Aulostomoidea (Wheeler, 1955; Fritzsche, 1976, 1981; Blot, 1980; among others). Abbreviations: Abd, abdominal.

\begin{tabular}{|c|c|c|c|c|c|c|c|c|}
\hline & 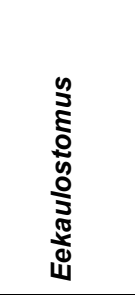 & 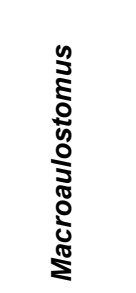 & 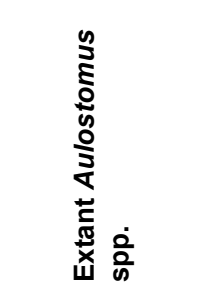 & 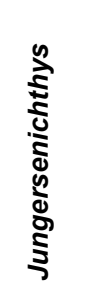 & 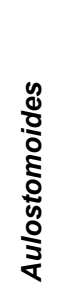 & 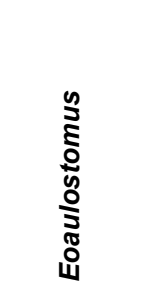 & 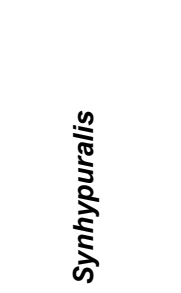 & 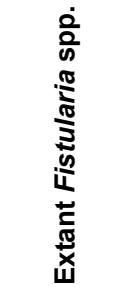 \\
\hline Dorsal fin & $I I+8$ & $?+(15) ?$ & VIII-XIII + 21-26 & - & - & III +16-21 & $\begin{array}{c}\text { II or III +14- } \\
15\end{array}$ & $-+14-20$ \\
\hline Dorsal spines & Stout & $?$ & Thin, large & - & - & $?$ & $?$ & No \\
\hline Anal fin & $11+8$ & $?+14 ?$ & III + 23-27 & - & - & III + 16-20 & $\| I I I+12-13$ & $0+14-19$ \\
\hline Anal fin spines & Stout & - & Thin & - & - & $?$ & $?$ & - \\
\hline Pectoral fin rays & 15 & - & $?$ & - & - & 15 & $15-16$ & $13-18$ \\
\hline Pelvic fin & Thoracic & Anterior? & $\mathrm{Abd}$ & - & Abd & Abd & $?$ & Abd \\
\hline Pelvic fin rays & 6 & 6 & 5 & - & - & 6 & 6 & 6 \\
\hline Caudal fin formula & $\begin{array}{c}\mathrm{iv}+1+7 \\
- \\
5+1+i i i\end{array}$ & $\begin{array}{c}\mathrm{iii}+\mathrm{I}+5 \\
- \\
5+1+\mathrm{iii}\end{array}$ & $?$ & $(15) ?$ & - & $\begin{array}{c}i v+1+5 \\
- \\
5+1+i v\end{array}$ & $\begin{array}{c}\mathrm{iii+l+5} \\
- \\
5+1+\mathrm{iii}\end{array}$ & $\begin{array}{c}0+1+6 \\
- \\
6+1+0\end{array}$ \\
\hline Caudal filament & No & No & No & No & $?$ & Yes & Yes & Yes \\
\hline
\end{tabular}

others). Although these characters help to differentiate the species; they do not help in resolving their phylogenetic relationships within the superfamily Aulostomoidea (Table 3). Today, obtaining a robust phylogenetic hypothesis of aulostomoids including the extant and fossil species is an unsolvable task because most of these fossils still require an accurate description.

The occurrence of scutes covering the whole trunk and part of the head of Eekaulostomus cuevasae gen. and sp. nov. may be considered as a plesiomorphic character among aulostomoids, which is present in some of its fossil species. Although Wiley and Johnson (2010, p. 154) listed the presence of "plates or scutes" as a diagnostic character of Gasterosteiformes; according Johnson and Patterson (1993, p. 579), the presence of "peripheral ctenoid scales" in Aulostomus is a "secondary developed" character. Considering this context, the scaleless body of Fistularia, which has been described as partially covered with aligned scutes and spinules or prickles (Fritzsche, 1981; Nelson et al., 2016), also represents a secondarily derived character, developed in parallel with Aulostomus.

Among the fossil species related to the aulostomoids aforetime recovered from the Eocene and younger strata along Europe, there are species displaying peculiar mixtures of characters of both extant aulostomoid families (Aulostomidae and Fistulariidae) (Table 3). Based on the few characters described, it is possible to see some general tendencies that deserve additional research. These tendencies start in the Paleocene with the oldest aulostomoid fish, Eekaulostomus cuevasae gen. and sp. nov., continuing with the Eocene aulostomoids of Europe, and ending with the living aulostomoids. Such tendencies include the progressive reduction in the elements of the caudal fin (procurrent and principal rays), the modification of the spines in dorsal fin, the reduction of spines in the anal fin, and the development of the caudal fin filament, as well as the possible change in position of the pelvic fin from the pectoral to the middle abdominal region. Eekaulostomus and the European Eocene aulostomoids also may be showing the transition of the body coverage along the Paleocene-Eocene, from fishes fully armored with scutes toward agile nude species as Fistularia.

The superfamily Centriscoidea (Macrorhamphosoidea sensu Natale, 2008) or its members have been related with the aulostomoids. This group includes two families (Figure 6), Macrorhamphosidae [involving the genera Macrorhamphosus 
Lacépède, 1803 (2 spp.); Notopogon Regan, 1914 (5 spp.); and Centriscops Gill, 1862 (1 sp.)] and Centriscidae [constituted by Aeoliscus Jordan and Starks, 1902, including two living and about eight extinct species (see Parin and Micklich, 1996b; Schultz, 2006), and Centriscus Linnaeus, 1758, with two living species and post-Oligocene fossil representatives)], as well as some fossil taxa as Gasterorhamphosus zuppichinii Sorbini, 1981; Paraeoliscus robinetae Blot, 1980; and Protorhamphosus Danil'chenko, 1968 (2 spp, see Tyler, 2004; Bannikov and Tyler, 2006; Tyler and Bannikov, 2011a; among others); Paramphisile weileri Blot, 1980; Veronarhamphus canossae Tyler and Bannikov, 2011b; Pesciarhamphus carnevalei Tyler and Bannikov, 2011b, and Gerpezhus paviai Bannikov and Carnevale, 2012. It is noticeable that the interrelationships of these putative fossils centriscoids have not been properly analyzed phylogenetically; however, the ovoid and short bodies of the case of extant centriscoids clearly differ from those elongated bodies present in Eekaulostomus cuevasae gen. and sp. nov. and other aulostomoids.

Gasterorhamphosus, collected in the Campanian-Maastrichtian marine deposits of Nardo, Italy, is the oldest fossil centriscoid and the single Cretaceous member of the family Macrorhamphosidae; however, Johnson and Patterson (1993) suggested that it might be a stem gasterosteiform or probably it branches from the common stem of Macrorhamphosidae and Centriscidae as noted by Orr (1995), Natale (2008), and Friedman (2009). In any case, the late Cretaceous age of Gasterorhamphosus indicates that centriscoids and aulostomoids already form two distinct lineages since before the massive extinction event of the Cretaceous-Tertiary.

\section{CONCLUSIONS}

Fossils referring to the superfamily Aulostomoidea had been collected more than 200 years ago in Eocene and younger marine deposits along Europe. Although the extant aulostomoids form part of large modern cladistics essays, some are based on morphological evidences and others on molecular data; unfortunately, the fossil aulostomoids have never been phylogenetically studied. This situation has prevented the generation of a robust classification of the aulostomoids, and at the same time, has fueled the differences and contradictions between the phylogenetic hypotheses already published. It is so, that it is desirable to make these European fossils part of future cladistic studies; however, first we have to fulfill the task of re-describing them accurately using modern and homogeneous criteria. Only up to the present day, the distribution of fossil aulostomoids was restricted to Europe. Although this fact has not interested paleontologists outside of Europe to further collaborate in studies concerning the diversity evolution of aulostomoids; the goal of this paper is to provide the first tangible evidence that in the past, this fish group was also an inhabitant of the American seas.

From now on, we must take more seriously the paleontological surveys on late Cretaceous and early Paleocene sites with marine sediments present throughout the tropical region of America. As present study shows, fossils may exist that allow us to delve into the details of the evolution of the fishes on both sides of Cretaceous-Tertiary mass extinction event. Sadly, during the joint INAHUNAM project, from which this article was drawn, no other fossil aulostomoid was recovered; however, the collection effort applied in Belisario Domínguez (where Eekaulostomus cuevasae gen. and sp. nov. came) as well as in its coeval and neighbor quarry, División del Norte, both with Danian marine sediments, really is far from reaching saturation.

The re-examination of the relationships of the Aulostomoidea executed here, using datasets previously generated by other authors and including Eekaulostomus cuevasae gen. and sp. nov., might not be the best way to achieve the desired understanding on the evolutionary processes of these fishes; however, this exercise significantly contributes to this goal. On the one side, the undeniable position of this new species as a primitive aulostomoid member, together with its deep morphological differences with other extinct and living taxa formally, or putatively, included in such superfamily, trace possible trends in morphological changes experienced by these fishes since the Paleocene to the present. This essay also widens the geographical scenario where the evolution of these fishes took place, extending from Europe to the tropical region of America.

\section{ACKNOWLEDGMENTS}

We owe our gratitude to $A$. Montejo and his family because this research was made possible by their enthusiasm, support, and help during the prospecting and collecting of fossils in the Belisario Domínuez quarry. This work, as well as the entire archaeological-paleontological project in the region 
of Palenque, was financially supported by the INAH (Grant 2008-2009) and UNAM (projects DGAPA-PAPIIT IN106011 and IN207314.). UNAM provided an additional support to KMC through a DGAPA postdoctoral grant. Many thanks to the Handling Editor K. Claeson and the style editor K. Travouillon by textual corrections and suggestions. We thank to J. Rumford and J. Louys for their editorial help. Useful commentaries and advices from P.M. Brito, C. Cupello, G. Machado, I. Vazquez, and $\mathrm{Y}$. Modesto also improved this manuscript. Thanks to L.P. Machado and J.M. Contreras for photos included in this manuscript. We are grateful to Museum National d'Histoire Naturelle (MNHN), the California Academy of Sciences (CAS), the Biodiversity Heritage Library project (BHL), and the "Fossil forum" to provide information about biodiversity, literature, type information, and pictures open available of aulostomoid fishes.

\section{REFERENCES}

Agassiz, J.L.R. 1833. Recherches sur les poissons fossiles (Tome I). Neuchâtel et Soleure, Petitpierre, Switzerland.

Agassiz, J.L.R. 1839. Recherches sur les poissons fossiles (Tome 3). Neuchâtel et Soleure, Petitpierre, Switzerland.

Agassiz, J.L.R. 1842. Recherches sur les poissons fossiles (Tome 4). Neuchâtel et Soleure, Petitpierre, Switzerland.

Alaniz-Galvan, A. 2011. Primer registro de perciformes fósiles paleocénicos de Palenque, Chiapas, México. Unpublished Bachelor's degree Thesis, Facultad de Ciencias, Universidad Nacional Autónoma de México, D.F., Mexico.

Alaniz-Galvan, A. and Alvarado-Ortega, J. 2011. Un "Serranido" del Paleoceno de Palenque, Chiapas, y sus implicaciones en la comprensión de la evolución de los Percomorfos. XII Congreso Nacional de Paleontología; Sociedad Mexicana de Paleontología; Edificio Carolino, Benemérita Universidad Autónoma de Puebla; Puebla, México; Libro de Resúmenes p. 27.

Alvarado-Ortega, J., Cuevas-García, M., MelgarejoDamián, M.P., Cantalice, K.M., Alaniz-Galvan, A., Solano-Templos, G., and Than-Marchese, B.A. 2015. Paleocene fishes from Palenque, Chiapas, southeastern Mexico. Palaeontologia Electronica 18.2.39A: 1-22 palaeo-electronica.org/content/2015/ 1282-paleocene-fishes-from-palenque.

Bannikov, A.F. 1993. The succession of the Tethys fish assemblages exemplified by the Eocene localities of the southern part of the former USSR. Kaupia, 2:241246.

Bannikov, A.F. 2014. The systematic composition of the Eocene actinopterygian fish fauna from Monte Bolca, northern Italy, as known to date. Studi e ricerche sui giacimenti terziari di Bolca, XV-Miscellanea Paleontologica, 12:23-34.

Bannikov, A.F. and Carnevale, G. 2012. A long-bodied centriscoid fish from the basal Eocene of KabardinoBalkaria, northern Caucasus, Russia. Naturwissenschaften, 99:379-389. doi 10.1007/s00114-0120912-6.

Bannikov, A.F. and Tyler, J.C. 2006. A new species of the genus Aulorhamphus (Gasterosteiformes: Aulorhamphidae) from the Eocene of the Caucasus in southwestern Russia. Proceedings of the Biological Society of Washington, 119(1):143-149.

Berg, L.S. 1940. Classification of fishes, both recent and fossil. Trudy Zoologicheskogo Instituta Akademii Nauk SSSR, 5:87-517.

Betancur-R., R., Broughton, R.E., Wiley, E.O., Carpenter, K., López, J.A., Li, C., Holcroft, N.I., Arcila, D., Sanciagco, M., Cureton II, J.C., Zhang, F., Buser, T., Campebell, M.A. Ballesteros, J.A., Roa-Varon, A., Willis, S., Borden, W.C., Rowley, T., Reneau, P.C., Hough, D.J., Lu, G., Grande, T., Arratia, G., and Ortí, G. 2013a. The Tree of Life and a New Classification of Bony Fishes. PLOS Currents Tree of Life. doi: $10.1371 /$ currents.tol. caee75bb165c8c2628.

Betancur-R., R., Li, C., Munroe, T.A., Ballesteros, J.A., and Ortí, G. 2013b. Addressing gene-tree discordance and non-stationarity to resolve a multi-locus phylogeny of the flatfishes (Teleostei: Pleuronectiformes). Systematics Biology, 62(5):763-785.

Betancur-R., R., Ortí, G., and Pyron, A. 2015. Fossilbased comparative analyses reveal ancient marine ancestry erased by extinction in ray-finned fishes. Ecological Letters, 18:441-450.

Blainville, H.M.D. 1818. Sur les ichthyolites, ou, Les poissons fossiles. D'Abel Lanoe, Paris.

Blot, J. 1980. La faune ichthyologique des gisements du Monte Bolca (Province de Verone, Italie). Bullettin du Museum d'Histoire Naturelle, 4:339-396.

Böhme, M. and Ilg, A. 2003. Aulostomoidea fossil occurrence and distribution, accessed on 5 March 2016. Fossil Fishes, Amphibians, Reptiles-fosFARbase. www.wahre-staerke.com.

Bonde, N.C. 1997. A distinctive fish fauna in the basal ash-series of the Fur/Ølst Formation (U. Paleocene, Denmark). Aarhus Geoscience, 6:33-48.

Bonde, N., Andersen, S., Hald, N., and Jakobsen, S.T. 2008. Danekræ-Danmarks bedste fossiler. Gyldendal, Copenhagen.

Britz, R. and Johnson, G.D. 2002. "Paradox lost": skeletal ontology of Indostomus paradoxus and its significance for the phylogenetic relationships of Indostomidae (Teleostei, Gasterosteiformes). American Museum Novitiates, 3383:1-44.

Calendini, F. and Martin, J.F. 2005. PaupUP v1.0.3.1. A free graphical frontend for Paup* Dos software.

Carnevale, G., Bannikov, A.F., Marramá, G., Tyler, J.C., and Zorzin, R. 2014. The Pesciara-Monte Postale Fossil-Lagerstätten: 2. Fishes and other vertebrates. 
The Bolca Fossil-Lagerstätten: A window into the Eocene World. Rendiconti della Società Paleontologica Italiana, 4:37-63.

Chen, W.J., Bonillo, C., and Lecointre, G. 2003. Repeatability of clades as a criterion of reliability: a case study for molecular phylogeny of Acanthomorpha (Teleostei) with larger number of taxa. Molecular Phylogenetics and Evolution, 26:262-288.

Chen, W.J., Santini, F., Carnevale, G., Chen, J.N., Liu, S.H., Lavoué, S., and Mayden, R.L. 2014. New insights on early evolution of spiny-rayed fishes (Teleostei: Acanthomorpha). Frontiers in Marine Science, 1(53):1-17.

Cuevas-García, M.J. and Alvarado-Ortega, J. 2008. El Mar de la Creación primordial: un escenario mítico y geológico en Palenque. VI Mesa Redonda de Palenque-Arqueología, Imagen y Texto-, Homenaje a Ian Graham. Instituto Nacional de Antropología e Historia, 16-21 octubre, Palenque, Chiapas. Libro de Ponencias, p. 15-16.

Cuevas-García, M. and Alvarado-Ortega, J. 2009. Estudio arqueológico y paleontológico de los fósiles marinos que proceden del sitio de Palenque, Chiapas. Informe de la primera temporada de campo 2008. Instituto Nacional de Antropología e Historia, 54 p.

Cuvier, G. 1816. La régne animal distribué d'aprés son organisation, pur servir de base à l'histoire naturelle des animaux et d'introduction à l'anatomie compare. Avec figures, dessinées d'après nature (Tome 5). Chez Deterville, Paris.

Danil'chenko, P.G. 1960a. Kostistye ryby maǐkopskikh otlozhenil̆ Kavkaza. Trudy Paleontologichenkogo Instituta, Akademiya Nauk SSSR, 78:1-208 (Translated from Russian by A. Mercado, edited by Joyce Joffe, published as: Danil'chenko, P.G. 1960. Bony fishes of the Maikop deposits of the Caucasus. Jerusalem, Israel Program for Scientific Translations, vii+247 p.)

Danil'chenko, P.G. 1960b. Bony fishes of the Maikop deposits of the Caucasus. Izdatel'stvo Akademii nauk SSSR Moskva, 78:3-207. (In Russian, translated in English by the Israel Program for Scientific Translation 1967).

Danil'chenko, P.G. 1968. Ryby verkhnego paleotsen a Turkmenii [Fishes of the Upper Paleocene of Turkmenistan], p. 113-156. In Obruchev, N.Y. (ed.), Ocherki po filogenii $i$ sistematike iskopayemykh ryb $i$ beschelyustnykh [Works on the phylogeny and systematics of fishes and agnathans]. Nauka, Moscow.

Dettai, A. and Lecointre, G. 2005. Further support for the clades obtained by multiple molecular phylogenies in the acanthomorph bush. Comptes Rendus Biologies, 328:674-689

Dettai, A. and Lecointre, G. 2008. New insights into the organization and evolution of vertebrate IRBP genes and utility of IRBP gene sequences for the phylogenetic study of the Acanthomorpha (Actinopterygii: Teleostei). Molecular Phylogenetics and Evolution, 48:258-269.
Eastman, C.R. 1914. Catalog of the Fossil Fishes in the Carnegie Museum, Part IV: Descriptive Catalog of Fossil Fishes from the Lithographic Stone of Solenhofen, Bavaria. Carnegie Museum, Pittsburgh.

Eschmeyer, W.N., Fricke, R., and van der Laan, R. 2016. Extant Aulostomidae and Fistulariidae diversity data, accessed on 5 March 2016. California Academy of Sciences Catalog of fishes: genera, species. http:// researcharchive.calacademy.org/ research/ichthyology/catalog/fishcatmain.asp.

Felsenstein, J. 1985. Confidence limits on phylogenies: an approach using the bootstrap. Evolution, 39:783791.

Friedman, M. 2009. Ecomorphological selectivity among marine teleost fishes during the End-Cretaceous extinction. Proceedings of the National Academy of Sciences, 106(13):5218-5223.

Fritzsche, R.A. 1976. A review of the cornetfishes, genus Fistularia (Fistulariidae), with a discussion of intrageneric relationships and zoogeography. Bulletin of Marine Sciences, 26(2):196-204.

Fritzsche, R.A. 1981. Families Fistulariidae and Aulostomidae, p. 1226-1228. In Fischer, W. (ed.), FAO Species Identification Sheets for Fishery Purposes. Eastern Central Atlantic. (Fishing Areas 34, 47 (in part)). Food and Agriculture Organization, United Nation.

Froese, R. and Pauly, D. 2016. Extant Aulostomidae and Fistulariidae diversity and distribution, assessed on 5 March 2016. FishBase. http://www.fishbase.org.

Gill, T. 1862. Note on some genera of fishes of western North America. Proceedings of the Academy of Natural Sciences of Philadelphia, 1862:329-332.

Gill, T. 1872. Arrangement of the families of fishes, or classes Pisces, Marsipobranchii, and Leptocardii. Smithsonian Miscellaneous Collections, 247:1-49.

Gill, T. 1884. On the mutual relations of the hemibranchiate fishes. Proceedings of the Academy of Natural Sciences of Philadelphia, 36:154-166.

Girone, A., Nolf, D., and Cavallo, O. 2010. Fish otoliths from the pre-evaporitic Early Messinian of northern Italy: their stratigraphic and paleobiogeography significance. Facie, 56:399-432.

Gosline, W.A. 1971. Functional morphology and classification of teleostean fishes. The University Press of Hawaii, Honolulu.

Greenwood, P.H., Rosen, D.E., Weitzman, S.H., and Myers, G.S. 1966. Phyletic studies of teleostean fishes, with a provisional classification of living forms. Bulletin of American Museum Natural History, 131(4):339-456.

Gregory, W.K. 1959. Fish skulls - a study of the evolution of natural mechanisms. Lundberg, Florida.

Johnson, G.D. and Patterson, C. 1993. Percomorph phylogeny: A survey of acanthomorph characters and a new proposal. Bulletin of Marine Sciences, 52:554626. 
Jordan, D.S. and Starks, E.C. 1902. A review of the Hemibranchiate fishes of Japan. Proceedings of the U.S. National Museum, 26:57-73.

Jungersen, H.F.E. 1910. Ichthyotomical contributions II. The structure of the Aulostomidae, Syngnathidae and Solenostomidae. Memmoires of Academy Royal Sciences Letters Denmark, 8(7):269-363.

Kawahara, R., Miya, M., Mabuchi, K., Lavoue, S., Inoue, J.G., Satoh, T.P., Kawaguchi, A., and Nishida, M. 2008. Interrelationships of the 11 gasterosteiform families (sticklebacks, pipefishes, and their relatives): a new perspective based on whole mitogenome sequences from 75 higher teleosts. Molecular Phylogenetics and Evolution, 46:224-236.

Keivany, Y. and Nelson, J.S. 2006. Interrelationships of Gasterosteiformes (Actinopterygii, Percomorpha). Journal of Ichthyology, 46:S84-S96.

Kner, R. and Steindachner, F. 1863. Neue Beiträge rur Kenntniss der fossilen Fische Öesterreichs. Denkschriften der Kaiserlichen Akademie der Wissenschaften in Wien, 21:17-36.

Lacépède, B.G.E. 1803. Histoire naturelle des poissons (Tome cinquième). Chez Plassant, Paris.

Li, B., Dettai, A., Cruaud, C., Couloux, A., DesoutterMeniger, M., and Lecointre, G. 2009. RNF213, a new nuclear marker for acanthomorph phylogeny. Molecular Phylogenetics Evolution, 50:345-363.

Linnaeus, C. 1758. Systema naturæ per regna tria naturæ, secundum classes, ordines, genera, species, cum characteribus, differentiis, synonymis, locis (tenth edition). Holmiæ, Stockholm.

Micklich, N. 1998. New information on the fish fauna of the Frauenweiler fossil site. Italian Journal of Zoology, 65(1):169-184. doi: 10.1080/11250009809386809.

Natale, M. 2008. II gasterosteiforme cretaceo Gasterorhamphosus zuppichinii Sorbini, 1981: analisi morfoanatomica e considerazioni sistematiche. Unpublished Master's degree Thesis, Facolta'di Scienze Matematiche Fische e Naturali, Universitadi Pisa, Italy.

Near, T.J., Dornburg, A., Eytan, R.I., Keck, B.P., Smith, W.L., Kuhn, K.L., Moore, J.A., Price, S.A., Burbrink, F.T., Friedman, M., and Wainwrigth, P.C. 2013. Phylogeny and tempo of diversification in the super radiation of spiny-rayed fishes. Proceedings of the National Academic Sciences, 110(31):12738-12743. doi:10.1073/pnas.1304661110.

Near, T.J., Eytan, R.I., Dornburg, A., Kuhn, K.L., Moore, J.A., Davis, M.P., Wainwright, P.C., Friedman, M., and Smith, W.L. 2012. Resolution of ray-finned fish phylogeny and timing of diversification. Proceedings of the National Academic Sciences, 109(34):1369813703.

Nelson, J.S. 2006. Fishes of the World (fourth edition). John Wiley \& Sons, New Jersey.

Nelson, J.S., Grande, T.C., and Wilson, M.V.H. 2016. Fishes of the World (fifth edition). John Wiley and Sons, New Jersey.
Orr, J.W. 1995. Phylogenetic relationships of Gasterosteiform fishes (Teleostei: Acanthomorpha). Unpublished PhD Thesis, University of Washington, Seattle, WA, USA.

Page, R.D. 2001. NDE (NEXUS data editor for windows). Version 0.5.0. Available on http://taxonomy.zoology.gla.ac.uk/rod/NDE/nde.html.

Parin, N.N. 1992. The first discovery of an Aulosphenid fish (Syngnathiformes) in the Oligocene of the northern Caucasus. Paleontologicheskii Zhurnal [Palaeontological Journal of the Russian Academy of Sciences], 4:85-88.

Parin, N.N. 1993. A new species of fossil shrimpfishes (Centriscidae, Syngnathiformes) from the upper Eocene of the Northern Caucasus. Journal of Ichthyology, 33(3):123-126.

Parin, N.N. and Micklich, N. 1996a. Two aulostomoid fish (Aulostomidae, Syngnathiformes) from the Lower Oligocene of Germany. Paleontologicheskii Zhurnal (Palaeontological Journal of the Russian Academy of Sciences), 30(1):61-66. (In Russian with English abstract).

Parin, N.N. and Micklich, N. 1996b. Fossil Gasterosteiformes from the Lower Oligocene of Frauenweiler (Baden-Württemberg, Germany). I. New information of the morphology and systematic of the genus Aeoliscus Jordan \& Starks, 1902. Paläontologische Zeitschrift, 70(3-4):521-545.

Pharisat, A. and Micklich, N. 1998. Oligocene fishes in the western Paratethys of the Rhine Valley Rift System: Italian Journal of Zoology, 65(1):163-168.

Pictet, A., Chablais, J., and Cavin, L. 2013. A new assemblage of ray-finned fishes (Teleostei) from the Lower Oligocene "Schistes a Meletta" from the Glieres plateau, Bornes Massif, eastern France. Swiss Journal of Geosciences, 106:279-289.

Pietsch, T.W. 1978. Evolutionary relationships of the sea moths (Teleostei: Pegasidae) with a classification of Gasterosteiform families. Copeia, 3:517-529.

Regan, C.T. 1909. The classification of teleostean fishes. The Annals and Magazine of Natural History, 3(8):7586.

Regan, C.T. 1914. Diagnoses of new marine fishes collected by the British Antarctic (Terra Nova) Expedition. Journal of Natural History, 13(73),11-17.

Roberts, C.D. 1993. Comparative morphology of spined scales and their phylogenetic significance in the Teleostei. Bulletin of Marine Science, 52:60-113.

Sauvage, H.E. 1880. Nouvelles recherches sur les poissons fossiles découvertes par M. Alby à Licata, en Sicile. Bibliothèque Ecole Haute Etudes, Secteur Sciences Naturelles, 20(4):1-50.

Schultz, O. 2006. Rasiermesserfische (Aeoliscus: Centriscidae, Osteichthyes) aus dem Badenium (MittelMiozän) von St. Margarethen im Burgenland, Österreich (Zentrale Paratethys). Annalen des Naturhistorischen Museums in Wien, 107A:71-85.

Smith, W.L. and Wheeler, W.C. 2004. Polyphyly of the mail-cheeked fishes (Teleostei: Scorpaeniformes), 
evidence from mitochondrial and nuclear sequence data: Molecular Phylogenetics and Evolution, 32:627-646.

Solano-Templos, G. and Alvarado-Ortega, J. 2013. Los peces fósiles de la Formación Tenejapa, Chiapas, México, p. 83. In Reynoso, V.H., Oseguera, B., and Flores-Mejía, P. (eds.), Programa y Resúmenes del VIII Congreso Latinoamericano de Paleontología y XIII Congreso Nacional de Paleontología. Sociedad Mexicana de Paleontología, A.C.-Museo Dugés, Universidad de Guanajuato. Guanajuato, México.

Song, H.Y., Mabuchi, K., Satoh, T.P., Moore, J.A., Yamanoue, Y., Miya, M., and Nishida, M. 2014. Mitogenomic circumscription of a novel percomorph fish clade mainly comprising "Syngnathoidei" (Teleostei). Gene, 542(2):146-155.

Sorbini, L. 1981. The cretaceous fishes of Nardo I. Order Gasterosteiformes (Pisces). Bollettino del Museo Civico di Storia Naturale di Verona, 8:1-27.

Swofford, D.L. 2002. PAUP* . Phylogenetic Analysis Using Parsimony ( ${ }^{*}$ and Other Methods). Version 4: Sinauer Associates, Sunderland, Massachusetts.

Than-Marchese, B.A., Velázquez-Velázquez, E., Alvarado-Ortega, J., Solano-Templos, G., Matamoros, W., and Carbot-Chanona, G. 2015, Los clupeomorfos fósiles de México; p. 59. In Reynoso V.H., Flores-Mejía, P., Aguilar, F., and Moreno-Bedmar, J.A. (coomp.). Programa y resúmenes del XIV Congreso Mexicano de Paleontología -Melchor Múzquiz, Coahuila, México; 19-24 de octubre, 2015. Sociedad Mexicana de Paleontología A.C.- Paleontología Mexicana, volumen especial 1.

Tyler, J.C. 2004. Review of the species of the Eocene of Monte Bolca, Italy, fish family Aulorhamphidae, new, related to Gasterosteiformes. Museo Civico di Storia Naturale di Verona, Miscellanea Paleontologica 7,
Studi e Ricerche sui Giacimenti Terziari di Bolca, 10:37-54.

Tyler, J.C. and Bannikov, A.F. 2011a. A new species of Aulorhamphus fish from the Eocene of Monte Bolca, Italy (†Aulorhamphidae, basal Gasterosteiformes). Studi e ricerche sui giacimenti terziari di Bolca, Miscellanea paleontologica, 13:37-45.

Tyler, J.C. and Bannikov, A.F. 2011b. An informative new specimen of the fish Veronarhamphus canossae from the Eocene of Monte Bolca, Italy (†Aulorhamphidae, basal Gasterosteiformes). Studi e ricerche sui giacimenti terziari di Bolca, Miscellanea paleontologica, 13:47-55.

Tyler, J.C. and Bannikov, A.F. 2011c. New genus and species of aulorhamphid fish (Aulorhamphidae, basal Gasterosteiformes) from the Eocene of Monte Bolca, Italy, with a unique first-dorsal-fin pterygiophore placement. Studi e Ricerche sui giacimenti Terziari di Bolca, XIII Miscellanea Paleontologica, 10:57-65.

Weiler, W.W. 1920. Die Septarientonfische des Mainzer Beckens. Jahrbücher des Nassauischen Vereins für Naturkunde, 72:2-15.

Wheeler, A.C. 1955. Preliminary revision of the fishes of the genus Aulostomus. Annals and Magazine of Natural History, 12(8):613-623.

Wiley, E.O. and Johnson, G.D. 2010. A teleost classification based on monophyletic groups, p. 123-182. In Nelson, J.S., Schultze, H.-P., and Wilson, M.V.H. (eds.), Origin and Phylogenetic Interrelationships of Teleosts. Verlag Dr. Friedrich Pfeil, München.

Wilson, A.B. and Orr, J.W. 2011. The evolutionary origins of Syngnathidae: pipefishes and seahorses. Journal of Fish Biology, 78:1603-1623.

Zigno, A. 1887. Nuove aggiunte alla ittiofauna dell'epoca Eocena. Memorie dell'Istituto Veneto di Scienze. Lettere ed Arti, 23:9-33. 


\section{APPENDIX 1}

List of characters used to on the phylogenetic analysis performed in this work. Characters 111 to 113 are proposed in this manuscript, the others are from Keivany and Nelson (2006, appendix $2)$;

1. Shape of nasal: 0) Simple, flat; 1) With anterior lamina; 2) Absent.

2. Lateral ethmoid: 0) Not extended to the orbit; 1) Extended to the orbit.

3. Vomer location: 0) Between ethmoids; 1) Superficially anteriorly.

4. Lachrymal: 0) Short; 1) Elongated.

5. Infraorbitals: 0) Discontinuous; 1) Continuous.

6. Frontal lateral postorbital process: 0) Absent; 1) Present.

7. Frontal: 0) Does not meet paresphenoid lateral process; 1) Meeting paresphenoid lateral process.

8. Parietal: 0) Present; 1) Absent.

9. Intercalar: 0) Present; 1) Absent.

10. Prootic and exoccipital: 0) Connected; 1) Widely separated by pterotic.

11. Basisphenoid: 0) Present; 1) Absent.

12. Pterosphenoid: 0) Present; 1) Absent.

13. Paresphenoid: 0) Narrow; 1) Expanded between the lateral ethmoids.

14. Paresphenoid shaft: 0) Divided posteriorly; 1) Entire.

15. Occipital condyle: 0) Concave; 1) Convex.

16. Exoccipital elongated posterior process: 0) Absent; 1) Present.

17. Spina occipitalis: 0) Present; 1) Absent.

18. Teeth on the jaws: 0) Present; 1) Absent.

19. Premaxillary ascending process: 0) Well developed; 1) Absent or reduced.

20. Premaxillary articular process: 0) Present; 1) Absent.

21. Premaxillary postmaxillary process: 0) Absent; 1) Present.

22. Maxillary shaft: 0) Expanded ventrally; 1) Uniform.

23. Maxillary posterior process: 0) Present; 1) With an anterior lamina; 1) Absent.

24. Palatine: 0) Separated; 1) United at the midline and to vomer.

25. Palatine head: 0) Cylindrical; 1) Conical.

26. A separated entopterygoid: 0) Present; 1) Absent.

27. Metapterygoid: 0) Separate; 1) Fused to hyomandibular or sympletic.

28. Metapterygoid: 0) Posterior; 1) Anterior to the orbit.
29. Quadrate shaft: 0) Lacks a deep dorsal flange; 1) Bears a deep dorsal flange.

30. Length of the quadrate shaft: 0) About the same that quadrate body; 1) Much longer than quadrate body.

31. Articulation of quadrate and lower jaw: 0) Below the orbit; 1) In front of the orbit.

32. Sympletic: 0) Lacking a dorsal or ventral flange; 1) Bearing a dorsal or ventral flange; 2) Bifurcated anteriorly.

33. Hyomandibular: 0) Lacking a large medial lamina; 1) Bearing a large medial lamina.

34. Hyomandibular: 0) Bearing a lateral lamina; 1) Lacking a lateral lamina.

35. Hyomandibular: 0) Bearing distinct cranial condyles; 1) Lacking distinct cranial condyles.

36. Preopercle: 0) Without socket at articulation with interhyal; 1) With socket at articulation with interhyal.

37. Ventral and dorsal arms of the preopercle: 0) Different sized; 1) Equal sized.

38. Preopercular canal: 0) Enclose; 1) Open.

39. Ascending limb of subopercle: 0) Present; 1) Absent.

40. Subopercle and interopercle: 0) Close together; 1) Widely separating from each other.

41. Interopercle: 0) Short; 1) Elongated.

42. Posteroventral expansion of the interopercle: 0 ) Absent; 1) Present.

43. Basihyal: 0) Small; 1) Elongated; 2) With enlarged anterior cartilage.

44. Urohyal: 0) Without ventrolateral flanges; 1) With ventrolateral flanges.

45. Urohyal blade: 0) Entire; 1) Incised posteriorly.

46. Hypohyals: 0) Overlap anterior ceratohyal; 1) Articulate with posterior ceratohyal.

47. Anterior ceratohyal: 0) Abruptly becoming narrower; 1) Even or gradually becoming narrower anteriorly.

48. Struts that connects anterior and posterior ceratohyals: 0) Present; 1) Absent.

49. Interhyal: 0) Cylindrical and free; 1) Round and sutured to the posterior ceratohyal.

50. Branchiostegal rays: 0) More than four; 1) Four or fewer.

51. Gill membrane: 0) Free from isthmus; 1) United to isthmus.

52. Ossified basibranchials: 0) Three; 1) Less than three. 
53. A fourth cartilaginous basibranchials: 0) Present; 1) Absent.

54. Hypobranchials: 0) Three; 1) Fewer than three.

55. Epibranchial 1: 0) With uncinated process; 1) Without uncinated process.

56. Epibranchial 1: 0) Separate to pharyngeal tooth plate 2 ; 1) Attached to pharyngeal tooth plate 2 .

57. Uncinated process of epibranchial 3 and 4: 0) Present; 1) Absent.

58. Epibranchial 3 and 4: 0) Not associated with their processes or heads; 1) Associated with their processes or heads.

59. Epibranchial 4: 0) Normal; 1) Enlarged; 2) Absent.

60. Epibranchial 4 head: 0) Larger than three; 1) Normal.

61. Pharyngobranchial 1: 0) Present; 1) Absent.

62. Pharyngeal tooth plate 2: 0) Present; 1) Absent.

63. Pharyngeal tooth plate 4: 0) Present; 1) Absent.

64. Interarcual cartilage: 0) Absent; 1) Present.

65. Gill filaments: 0) Normal; 1) Lophobranch with skeleton fused basally.

66. Tooth plates on the branchial arches: 0) Present. 1) Absent.

67. Posttemporal dorsal process: 0) Tightly attached with short ligament to epioccipital; 1) Ossified to cranium.

68. Posttemporal sensory canal: 0) Absent; 1) Present.

69. Extrascapular: 0) Present; 1) Absent.

70. Supracleithrum: 0) Normal; 1) Reduced or absent.

71. Pointed anterodorsal ramus of the cleithrum: 0) Present; 1) Absent.

72. Cleithrum: 0) Entire; 1) Divided into two struts ventrally.

73. Cleithrum: 0) Without posteromedial extension to coracoids; 1) With posteromedial extension to coracoids.

74. Postcleithrum number: 0) Two; 1) One; 2) Absent.

75. Scapular foramen: 0) Complete; 1) Incomplete.

76. Scapula and first actinost: 0) Separate; 1) Fused together.

77. Coracoid ventral flange: 0) Present; 1) Absent.

78. Ectocoracoid: 0) Absent; 1) Present.

79. Shape of actinost: 0) Normal; 1) Strongly hourglass-shaped.

80. Size of actinosts: 0) Different; 1) Similar.

81. Position of actinosts: 0 ) Normal; 1) Rotated laterally.

82. Anteroventral spike of actinost 4: 0) Absent; 1) Present.

83. Actinost 4 and coracoids sutured to each other: 0) Absent; 1) Present.
84. Pelvic spines: 0) Present; 1) Absent.

85. Pelvic plates: 0) Separated; 1) Joined by a suture.

86. Pelvic posterior process: 0) Present; 1) Absent.

87. Pelvic plate: 0) Lacking anterior process; 1) Bearing an anterior process.

88. Dorsal spines: 0) Present; 1) Absent.

89. Dorsal posterior basals: 0) Absent; 1) Present.

90. Dorsal spine distal pterygiophores: 0) Not expanding; 1) Expanding.

91. Number of anal spines: 0) More than one; 1) One; 2) Absent.

92. Dorsal part of occipital condyle: 0) Made of exoccipitals and the first centrum bearing a dorsal facet that articulate with the exoccipital condyles; 1) Occipital condyle consisting only of basioccipital and the first vertebra lacks the dorsal facet, but bears lateral facets that articulate with exoccipital; 2) The first vertebra directly connected only to the basioccipital.

93. Anterior centra: 0) Separate; 1) Sutured together.

94. Transverse process on the first two vertebrae: 0 ) Present; 1) Absent.

95. Anterior vertebrae: 0) Normal; 1) Longer than posterior one.

96. Anterior vertebrae: 0) Lack lateral process to scutes; 1) Bear lateral processes to scutes.

97. Neural arch of precaudal vertebra: 0) Not pierced by foramina; 1) Pierced by foramina.

98. Neurohypophyses: 0) Present; 1) Absent.

99. Number of supraneural bones: 0) Three; 1) One or two; 2) Absent.

100. Pleural ribs: 0) Present; 1) Absent.

101. Epineurals and epipleurals: 0) Both present; 1) Only epineurals present; 2) Both absent.

102. Baudelot's ligament: 0) Originates on the first vertebra; 1) Originates on exoccipital; 2) Absent.

103. Bony scutes: 0) Absent; 1) Present.

104. Parhypural: 0) Autogenous; 1) Fused to centrum or hypurals.

105. Condition of hypurals: 0) Autogenous; 1) All fused to centrum.

106. Number of hypural plates: 0 ) Three or more; 1) Two; 2) One.

107. Condition of hypurapophysis: 0) Distinct; 1) Indistinct.

108. Length of neural spine of preural 2: 0 ) Shorter than other preneurals; 1) The same size as other preneurals.

109. Condition of the uroneural 1: 0) Autogenous; 1) Fused.

110. Caudal cartilage: 0) Present; 1) Absent.

111. Interspace of dorsal spines: 0) Separate; 1) Close together. 
112. Snout: 0) Nude; 1) Covered with dermal scutes or scales.

113. Condition of postcleithrum: 0) Not posteriorly elongate (it does not reach the level of the poste- rior tip of the postcleithrum); 1) Posteriorly elongate (it reaches the posterior level of the postcleithrum). 


\section{APPENDIX 2}

List of states of characters considered to perform the phylogenetic analysis of the present paper

(Figure 6). Polymorphic states are coded as * =0/1, \#=0/2, @ = 1/2.

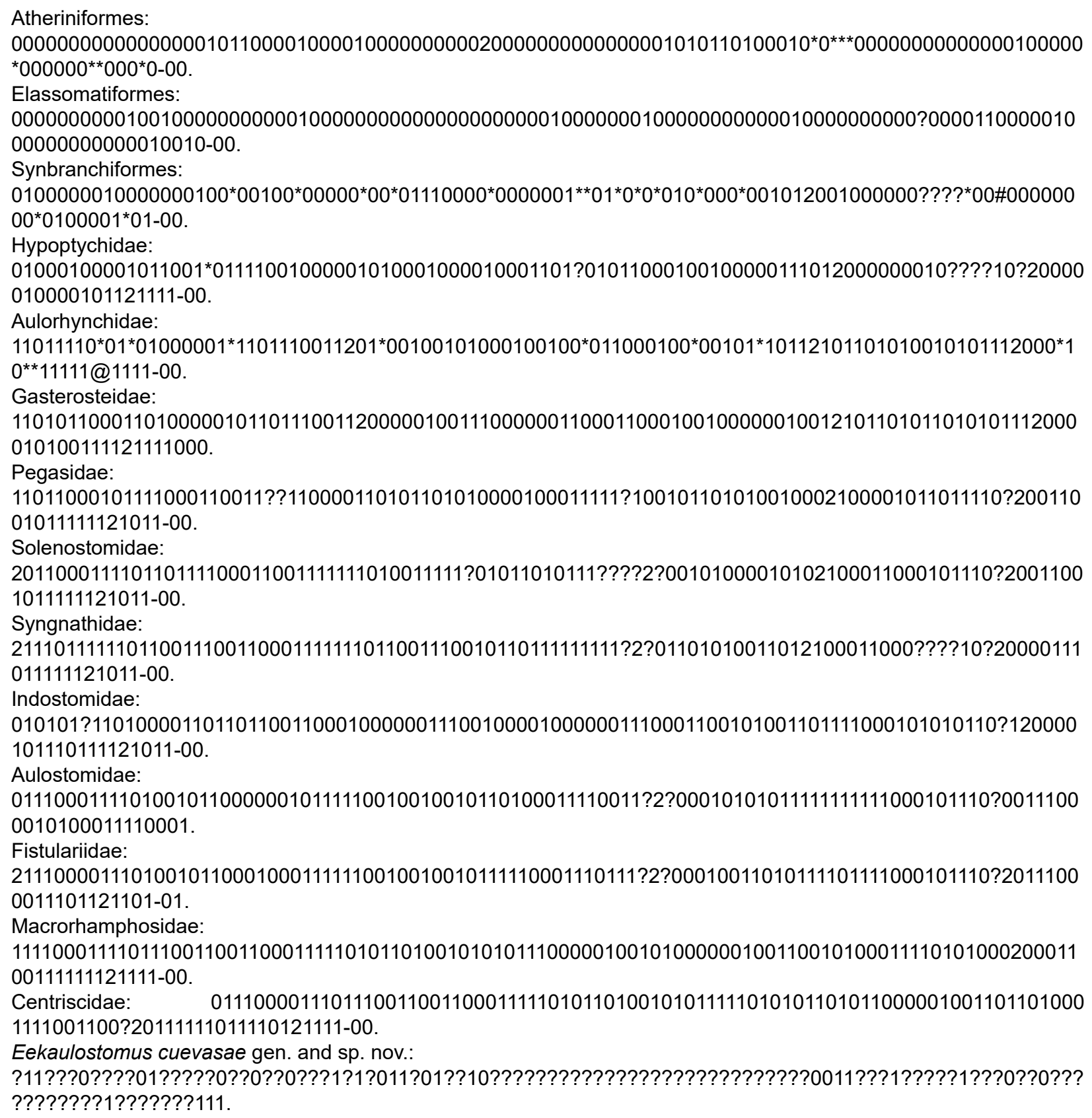




\section{APPENDIX 3}

Data matrix considered to perform the phylogenetic analyzes on the present work in NEXUS file format. The characters 1-110 and compared taxa are retrieved from Keivany and Nelson (2006). The characters 111-113 and Eekaulostomus cuevasae gen. and sp. nov. are added in this manuscript. Polymorphic states are represented by numbers separated by a slash (/) symbol. This file is available online at: palaeo-electronica.org/content/2016/1659-ancient-armored-trumpetfish. 